\title{
OVER DE DERDE PERSOON MEERVOUD IN HET AUSTRONESISCH.
}

\author{
DOOR \\ PATER H. GEEROMS C.I.C.M.
}

De derde persoon meervoud kan in de meeste Austronesische talen teruggebracht worden tot een van deze drie vormen: $d a$, iḍa siḍ. $D a$ is het persoonlijk voornaamwoord zonder meer; $i$ en si zijn de bekende persoonswijzers. In verscheidene talen hebben wij twee vormen naast elkaar, b.v. Pang. $r a^{1}$ ), ira; Il. da, ida; Cham. ha, siha; Fordaatsch $r(a)$, ira. Deze dubbelvormen hebben vaak een verschil in gebruik of beteekenis, die zoozeer van de functie van voornaamwoord kan afwijken, dat men ${ }^{2}$ ) ze niet meer als samenhoorend herkent en er allerlei vreemde interpretaties over is gaan nahouden. In andere gevallen bestaat slechts één vorm, de korte. Deze dwaalt meer dan eens van zijn oorspronkelijk gebruik af en geeft aanleiding tot groote misvattingen omtrent zijn natuur. In enkele gevallen is $d a$ als pronomen verdwenen, maar gebleven in verstarde restjes met een functie, die niet meer aan een voornaamwoord doet denken.

Zooals wij boven zeiden, is $d a$ als pronomen over het heele Austronesische gebied verbreid. Op grond hiervan is het aan geen twijfel onderhevig, dat het als dusdanig gebruikt werd in de oertaal. Wij kunnen niet aannemen, dat dit gebruik een latere ontwikkeling zou zijn, toen de talen uit elkaar waren gegaan. Toch zijn er schrijvers die er heel wat anders in zijn gaan zoeken. Wij citeeren hier alleen Codrington. De anderen komen later aan de beurt.

"This $r a^{3}$ ) is not the third person plural in Malay or in Malagasy,

1) Volgens de RLD wet. Zie Brandstetter, Common Indonesian and original Indonesian, n. 130.

2) Adriani N., Hoofdstukken uit de spr. van het Tontemboansch, p. 244 ; Sangir. spr. p. 239; Brandstetter, Common Indonesian and original Indonesian, n. 96; Geurtjens, VBG., D1. 63, 1922, p. 9; Williams H. W., Grammatische Skizze der Ilocano-Sprache, München, 1904, p. 48 enz.

3) $r a$ in Mota: ineira, Araga: ikera, beide met de beteekenis van $3 \mathrm{e}$ pers. mv. 
(though in the latter it is a plural sign, as it is in the Polynesian and Micronesian, nor is it in every Melanesian tongue. In claiming a common source for it, from whence it has come alike to Melanesia and Polynesia, it is not unreasonable to suppose that to use it as a Pronoun, third person plural, is a later product of the common language which has divided into the Malay and Malagasy, the Polynesian and the Melanesian branches, coming into use after the division had begun. The singular pronouns would come first into use, the plural later; a third person would satisfy for a time without distinction of number; as it is plain that in some of these languages, Malay and Melanesian, one form of the second person still suffices for one or many. In Malagasy the plural force of $r a$ shows itself, but the third person plural is not there developed. It is remarkable also that the inclusive and exclusive forms of the first person should seem to have preceded in time any form for the other persons of the plural" "1).

Codrington gaat hier in tegen meer dan een vaststaand feit in het Austronesisch. Ook is zijn opvatting moeilijk overeen te brengen met het princiep, algemeen anvaard in de taalkunde, dat men van het concrete overgaat tot het abstracte, en niet omgekeerd. Nu komt het ons voor, dat het concept van het persoonlijk voornaamwoord minder abstract is dan het teeken voor het plurale. Ook vindt men het eerste overal in de Archipel, het pluraalteeken als zoodanig niet. Trouwens uit ons verder betoog zal blijken, dat het juist andersom is gegaan.

Maar één ding heeft Codrington goed opgemerkt : $r a$ duidt in veel talen het meervoud aan. Hierop willen wij verder ingaan. Wij zullen alleen de feiten geven, zooals ze in de verschillende grammatika's, voor ons liggen, en niet zoeken naar taal-psychologische verklaringen. De meervoudige en daarmee verband houdende functies zullen afzonderlijk onderzocht worden. De indeeling van het materiaal is willekeurig. Wij onderzoeken $d a$ toegevoegd aan:

1. substantieven,

2. persoonlijke voornaamwoorden,

3. andere voornaamwoorden,

4. het lidwoord, of als lidwoord gebruikt woord.

Verder zullen wij dan, met behulp van dit materiaal en de conclusies die er uit voortvloeien, licht trachten te werpen op een paar punten, welke tot nog toe in het duister zijn gebleven.

1) Codrington, The Melanesian Languages, Oxford, 1885, p. 124 . 
$1^{0}$. De derde persoon meervoud is pluralisator bij substantieven.

In tegenstelling met de gewone werkmethode beginnen wij met Melanesië. Wij doen het zoo omdat het materiaal uit dit gebied het minst moeilijkheden oplevert. In verscheidene talen gesproken op de N. Hebriden is het pron. van de $3 \mathrm{e}$ pers. plur. meervoudsaanduider bij substantieven, nl. in het Baki, Aulua, Uripiv, Sinesip, Tasiko. Voorb. uit het Baki : veru nalo $=$ steenen (nalo $=3 \mathrm{e}$ pers. meerv.); kalisa nalo: jongens ${ }^{\mathbf{1}}$ ).

Fidji. "Another mode of distinguishing the numbers of the nouns in Fijian is by the personal pronouns: e. g. sing. O koya na tamata, the man. Plural. O ira na tamata, the men". De schrijver voegt er interessante gegevens aan toe omtrent het gebruik.

"The personal pronouns cannot be so used before all nouns. They are used. 1. Before rational beings, as gods, angels, devils and men ....; 2. Sometimes, but not generally, before the inferior animals .... : but the strict propriety of this use of them seems very doubtful, as general usage does not countenance it. 3. The latter remark applies with still greater force in reference to their use before vegetable and inanimate objects. O ira na kau may sometimes be heard, but the nouns then seem to be personified. 4. They cannot be used before nouns of action...." 2 ).

Fagani (San Cristoval). Sprekende over het meervoud der substantieven zegt Codrington: "There is no plural sign, except ra, which with pronouns 'applies to both things and men; a rima naera: these houses; rima: house " 3 ). Hier ter plaatse legt hij niet uit wat naera is, maar wat hooger zegt hij: "The demonstrative articles are $a$ and $n a$. Het pron. 3e pers. meervoud is in deze taal: iraira, -ra.

Mosin (Vanua Lava). "Plural. (Nouns). The noun tare means an assemblage; o tare: im (sic) houses; there is no other plural sign, except $r a$ with persons" $\left.{ }^{4}\right)$. Codrington geeft geen voorbeelden. Het pron. 3e persoon enkelvoud is : eni, ni; meervoud; enir, nir.

$\mathrm{Nu}$ komen wij op Indonesisch gebied.

Gadang (Phil.). ,De meest gewone wijze om het meervoud te vormen van de gemeene zelfst. naamw. bestaat hierin, dat men het partikel

1) Ray S. H., The Melanesian Island Languages, Cambridge, 1926, p. 236, 274, 285, 303.

$\left.{ }^{2}\right)$ Hazlewood D., A Fijan and English and an Engl. and Fij. Dic. and a Grammar, p. 11.

3) Codrington, The Melanesian Languages, Oxford, 1885, p. 500.

4) o.c., p. 350 . 
ira (3e pers. meerv.) toevoegt: tolay ira: de menschen; bahat ira: de plataanboomen" 1 ).

Batan (Phil.). Al het materiaal dat ik hierover bezit is een aanteekening op een tekst: "siraya, from sira (they) and aya (this); sira is often used to denote plurality“. Hier volgt het tekstverband: „Du makuyab nu nakavuya namen su isla siraya am nairaya kami $d u$ asaori du isla abnikan su Iami" ${ }^{2}$ ).

Veel materiaal geeft E. Stresemann in $\S 76$ van „Die Paulohisprache”. „Den Suffix-Neutren ( $(56)$ ist, falls sie die enklitische Form des Possessivpronomens bei sich führen, eine durchaus abweichende Pluralbildung eigentümlich, nämlich diejenige mit Hilfe der enklitischen 3. pers. pl. neutr. des Personalpronomens: $-r u$, welche dem Substantivum und seinem Possessivsuffix angefügt wird (Hilfsplural). Diese Bildungsweise stimmt principiell überein mit der Bezeichnung der Mehrzahl im Rotti, Kupang, Tettum, West-Timor und Buru. So lässt sich Rotti (Dial. v. Dengga) lima-n-eru (Handihre $^{3}$ )-sie) ihre Hände, wobei eru der Plural des Artikels ist und gleichzeitig mit dem pron. pers. der 3. pers. pl zusammenhängt $\left.{ }^{4}\right)$, direkt vergleichen mit paul. lima-si-ru: Hand-ihre ${ }^{5}$ )-sie. Auch die Endsilbe -ro, welche die Sprache von Tifu dem Substantivum zum Ausdruck des Plurals anfügt, dürfte sich auf das M. P. ra, das praefigierte Pron. pers. der 3. pers. plur. zurückführen lassen; ès würde dann wie ein nachgesetzter Artikel stehen: fatu Stein, fatu-ro (Stein sie), die Steine.

Eine Stütze findet diese Auffassung in dem Umstand, dass der Dialekt von Wolu (an der Talutibai, Südküste von Mittel-Seran), den Plural aller Substantiva unverkennbar mit Hilfe dieser Pronominalform bildet, also von seinen westlichen Verwandten in dieser Hinsicht sich wesentlich unterscheidet: hihina Frau, pl. hihina-lu (Frau sie); mau Kind (eig.: das Kleine), pl. mau-lu (Kind sie); fineu Kalong, pl. fineu-lu....

1) Martinena P. Fr. Is., Gramatica de la Lengua Gadang. Het exemplaar in mijn bezit is getypt. Voor zooveel ik weet, is deze grammatika niet gedrukt. Hij is gedateerd: Bayombong, 1889. Zie n. 46.

2) Scheerer O., Batan Texts with Notes. The Philippine Journal of Science, Manila, volume 31, No. 3, 1926.

3) ihre zou ik hier weg laten; $n$ zal wel een partikel zijn die dient om b.v. de bezitsverhouding aan te geven.

4) Het zal wel andersom zijn.

5) ihre lijkt mij weer onvoorzichtig uitgedrukt. De 3e pers. mv. zelfstandig gebruikt voor personen $=$ sile; wij zien in si- de persoonswijzer en in -le het eigenlijke pronomen. Gepraefigeerd of gesuffigeerd valt $l e$ weg en wij behouden alleen si. Historisch althans is het onjuist gezegd. 
Während nun im Rotti'schen der aus dem Personalpronomen abgeleitete Artikel sowohl dem Singular wie dem Plural des Substantivums angehängt werden kann, mag dasselbe mit einem Possessivsuffix versehen sein oder nicht (hatoli-a der Mensch, hatoli-la die Menschen, (ndia) mata- $n$ - $a$ sein Auge, (sila) mata- $n$-ala ihre Augen), hat er sich im Buru'schen nur im Plural der Substantiva erhalten. Das Paulohi schliesslich, das im Gegensatz zu den vorigen Sprachen die Spaltung der Substantiva in suffigierende und praefigierende bewahrt hat, wendet diese Form des Artikels nur im Plural hinter dem Possessivsuffix neutraler Substantiva an".

Boelisch (Cel.) Si (pron. 3e pers. plur.) wordt gevoegd aan volksnamen of persoonsnamen om het meerv. te vormen. B.v. Slamsi: mahomedanen, Gebsi: lieden van Gebe ${ }^{1}$ ).

Oost-Makiansch (Cel.) Hier hebben wij hetzelfde. B.v. mapinsi: vrouwen ${ }^{2}$ ).

Fordaatsch. ,In het Fordaatsch gebruikt men, om het meervoud aan te geven, een achtervoegsel, bestaande uit een enkele $r$. Ze wordt altijd uitgesproken met een zeer korten, doffen klinker als naslag, dien we niet schrijven.... Zoo klinkt de meervoudsvorm van het woord vata ....: vata-re, of vata-ra of vata-rô, dus de $r$ min of meer van het woord gescheiden.... Een bijzonderheid, die we hier best kunnen onderbrengen is, dat een kampongnaam of andere plaatsnaam tegelijk den bewoner van dien kampong of van die plaats aanduidt, en als zoodanig ook het meervoudsachtervoegsel kan aannemen. Kelaanr, de lui van Kelaan; Keljobarr, de lui van Keljobar ${ }^{3}$ )". De derde persoon meervoud luidt: ira, $r a, r$. Hier zal het meervoudsteeken gelijk zijn aan het pron. pers.

Jamdeensch. Om het meerv. van znw. aan te geven heeft men een achtervoegsel -ar; b.v. boeti, tiental, m.v.: boetjar; boeboe, vischfuik, mv. : boebwar. De derde persoon meervoud is: sira, $r a, r$. We meenen in het meervoudsteeken een metathesis te mogen zien van het pron. pers. Dit is echter slechts hypothese die wij vormen naar analogie van het pluraalteeken in het Fordaatsch en andere talen.

Slaroeëesch. Het meerv. van substantieven wordt gevormd met $r \breve{e}$. B.v. ir of iri: mensch, meervoud : irirĕ ; asoe : hond, meervoud asoerĕ. Het pron. $3 \mathrm{e}$ pers. meervoud is : $r, r a$. Wij denken, dat $r e$ hiermede

1) Adriani-Kruyt, Bare'e sprekende Toradja's, III, p. 330.

2) Ibid., p. 306.

3) Drabbe P., Spraakkunst der Fordaatsche Taal, VBG., Deel 67, eerste stuk, 1926 , n. 17,18 . 
verband houdt en dat $\breve{e}$ in $r \breve{e}$ een verzwakking is van $a$ in $r a$. We zagen hetzelfde, of iets dat er op lijkt, in het Fordaatsch.

Soembaneesch. Het enkv. wordt uitgedrukt door na, het meerv. door da. B.v. na oema: het huis; da oema: de huizen ${ }^{1}$ ). Het pron. 3e pers. luidt: Sing. Nom. njoena, Gen. na, Dat. nja, Acc. ja. Plur. Nom. njoeda, Gen. da, Dat. ndja, Acc. $h a^{2}$ ). Het is duidelijk dat $n a$ en $d a$, vertaald door het lidw., resp. enkv. en meerv., oorspronkelijk een pronominaal partikel zijn geweest.

Het Soembaneesch heeft deze eigenaardigheid, dat in de bezitsverhouding deze partikels tweemaal achter elkaar worden gebruikt. B.v. na ana na na maramba het kind van den vorst; na oema da da tau hoemba: het huis der Soembaneezen ${ }^{3}$ ).

Wielenga meent, dat het eerste $n a$ en $d a$ moet vertaald worden met het bepalend lidwoord ${ }^{4}$ ); wat het tweede $n a$ en $d a$ komt doen, zegt hij niet. M.i. is dat niet juist. Ik zou het willen formuleeren als volgt: $n a$ en $d a$ stonden aanvankelijk alleen vóór woorden in bezitsverhouding. Door het veelvuldig gebruik verstarden deze pronomina tot "lidwoorden", zooals blijkt uit na oema, da oema, waar oema niet in de bezitsverhouding staat. Om deze duidelijk aan te geven werden $n a$ en $d a$ herhaald.

Wij zullen deze partikels ook ontmoeten bij de demonstratieven.

Wahinama, (Ceram). Deze taal kent ook een pluralisator $r e$ in een bepaald geval, nl. wanneer het pronomen possessivum niet gesuffigeerd doch gepraefigeerd wordt. De voorbeelden zullen het duidelijk maken: ai-hata-re: ihre Körper ( $a i=3$ p. mv. als praefix); omihotare: eure Schwester; ita-ehe-re: unsere Brüder. Maar: hata-zerta: unsere Körper ${ }^{5}$ ). Iets dergelijks kent het Seleman (Ceram); re varieert hier met $r i$ of $r$ : b.v. tinina-re: Ohren; lesi-ri uni: Zahnfleisch ${ }^{6}$ ). Het pronomen 3e pers. meerv. luidt: sio, $i$ (alleen praefix). Zelfstandig gebruikt hebben wij ook: sio roin, ro.

Het is niet zoo duidelijk, of de pluralisator hier gelijk te stellen is met het pronomen dat in vorm, tenminste wat het Wahinama betreft, er heel wat verder afstaat dan in de vorige gevallen. Maar voor

1) Wielenga D. K., Schets van een Soembaneesche Spraakkunst, Batavia, 1909, p. 15.

2) Ibid., p. 26.

3) Ibid., p. 30 .

4) Ibid., p. 29.

$\left.{ }^{5}\right)$ Tauern O. Dr., Beitrag zur Kenntnis der Sprachen und Dialekte von Seran, Anthr. dl. 26, 1931, p. 111.

6) Tauern O. Dr., Anthr. d1. 24, 1930, p. 568. 
oogen hebbend wat vooraf gaat zijn wij geneigd het terug te brengen tot het Austronesische da.

Tettum. Het meervoud van woorden voor levende wezens kan gevormd worden door toevoeging van de 3e pers. meerv.: B.v. mánè sira: de menschen; labáric sira: de knapen ${ }^{\mathbf{1}}$ ).

Chamoro. ,In der Regel kennzeichnet man den Plural als solchen, und zwar durch das Wörtchen siha, welches entweder vor oder hinter das Substantiv gesetzt wird. Dieses siha ist identisch mit dem Fürwort der 3ten. Pers. Plur. und hat hier den Wert eines unbestimmten Fürwortes mit der Bedeutung ,welche, deren, mehrere, einige". gwaha siha gimas mu? gwaha gimas mu siha? - hast du Häuser? gwaha siha - ich besitze welche" ${ }^{2}$ ).

Polynesie. Wij geven hier het oordeel van Pater Schmidt. „Innerhalb der melanesischen Gruppe sind in den meisten (?) Sprachen eigene Suffixformen für den Plural nicht vorhanden ${ }^{3}$ ), in den anderen zeigt sich ein Ansatz dazu, indem die verkürzten Formen der Pluralpronomina herangezogen werden. Bei den polynesischen Sprachen kann auch im allgemeinen von eigenen Pluralsuffixen nicht gesprochen werden .... Der polynesische Plural ist ja eigentlich nichts anderes als ein Trial. Dieser Trial wird in den melanesischen Sprachen gebildet durch Anfügung des Zahlwortes für ,drei' an die eigentliche Pluralform, so dass das so entstandene Ganze dann so viel bedeutet als: Vielheit (und zwar) drei. Auch für den polynesischen Plural-Trial, der sich nur aus dem melanesischen Trial herausentwickelt hat, muss nun die Regel als massgebend gefordert werden, dass er gebildet werde durch Anhängung der Zahlform für ,drei’ an die Pluralform des Pronomens" 4 ).

Conclusie. In verscheidene Indonesische, Melanesische en Polynesische talen treedt de $3 e$ pers. meerv. op als pluralisator bij substantieven. Deze talen maken gewoonlijk geen onderscheid tusschen hetgeen door de zelfst. naamw. wordt uitgedrukt. Het Fidji, Tettum en Mosin maken hierop een uitzondering; de grammatika's zeggen duidelijk, dat deze meervoudsvorming alleen met personen of iets dgl. kan gebruikt worden. Misschien mogen wij vermoeden, dat, indien ons materiaal vollediger ware, wij nog elders deze distinctie zouden aantreffen. Maar hierop willen wij niet verder ingaan. Wij willen

1) Da Silba A., Diccionario Portuguez-Tétum, Macau, 1889, p. (4).

2) Costenoble, Die Chamoro Spr., p. 463.

3) Mijns inziens kan dat vraagteeken wegvallen.

4) Sitzungsberichte der wiener AK. der Wiss., Band 141, 1899, p. 19, 20. 
alleen nog aantoonen, dat het feit niet zoo zonderling en alleen staand is. Wat we hier hebben vinden wij ook elders. Prof. Royen schrijft het volgende over deze kwestie: „Von unmittelbarerer Bedeutung für die Gruppierung der Nomina sind einige Flexionsformen von Substantiven, namentlich die Pluralisierung in einigen Kreolisierten und indo-iranischen Sprachen.... Im Hottentotten-Afrikaans wird das Personalpronomen der dritten Person Mehrzahl hulle hinter pluralisierte Namen lebender Wesen gestellt. Von pa ,Vater', ma ,Mutter' lautet die Mehrzahl mit der Bedeutung ,Eltern': pa hulle, ma hulle; andere Beispiele sind: mijn baas hulle ,meine Herren'; boeti Dirk hulle ,Bruder Dirk und Familie'; moskoe hulle ,Mosku (Pferdename) und die Pferde seiner Koppel'. Dieses hulle entspricht semantisch dem Nama - gu, dem männlichen Pronomen conjunctum der dritten Person Mehrzahl, das auch als Pluralexponent fungiert: Khoi-b, der Mann': Khoi-gu ,die Männer', bzw. eig. ,Mann-er', ,Männ(er)-sie' (Planert, MSOS VIII Abt III 9, 13); vgl. N. 360. In Calvinia ist dieser Pluralexponent des Nama - $g u$ infolge Lautkontakt mit dem ndl. goed durch dieses niederländische ,Suffix' ersetzt worden, N. 353; so wurde -goed zum Pluralsuffix, teilweise Kollektivsuffix, bei Namen von Lebewesen: Jan-goed ,Jan und die Seinen', Elly-goed ,Elly und Familie', baas-goed ,Herren', frau-goed, Frau und Kinder' (Du Toit, Studies 27, 86 f., 90 f.; Van Ginneken, Handboek I 219 f.; Bouman, NT XVIII 126; vgl. Royen, Verand. N. 504).

Das pluralisierende Pronomen im Negerholländisch der Dänischen Antillen ist sender bei Dingnamen und Personen, sellie ausschliesslich bei Personennamen: die radies sender, die Rettiche', die volk sender ,die Menschen'. Auf analoge Weise wird im Neger-französischen von Haiti und Louisiana gesagt: Kaj layo, Kaj layé, cage-là + eux.... Im Ningre-tongo von Surinam kommt das pluralisierende Pronomen dem vor das Pronomen zu stehen. Im Papiamento dagegen findet suffixale Pluralisierung statt durch -nan, das u. a. von Fokker (TNTL XXXIII 62-65) mit dem Karibischen Pron. person. 3. plur. num identifiziert wird: e kas-nan ,die Häuser'. Sogar das Pronomen és lautet im Plural és-nan , die' ${ }^{1}$ ).

Deze gegevens deden mij vermoeden, dat wij in Afrikaansche talen hetzelfde verschijnsel zouden aantreffen als in het Austronesisch. Het was voor mij niet gemakkelijk, in deze omstandigheden, het

1) Royen G., Die nominalen Klassifikations-Systeme in den Sprachen der Erde, n. 370. 
materiaal te onderzoeken. Ik heb mij dan gewend tot P. L. De Boeck, Leuven; deze kon het met competentie doen. Hij is zoo vriendelijk geweest mij een overzicht te sturen van de meervoudspartikels en het pron. $3 \mathrm{e}$ pers. mv. Ik doe er een keuze uit.

\section{Meervoudsaffixen pron. 3e pers. mv.}

Ful

Twi :

Ewe

Gola

$$
\text { (mv. part.) }
$$

Tobote

Akasele

Gurma

More

Kusasi

Yoruba

Nyang

Mambila

Kassena

Malinke verscheiden suffixen

$$
\begin{aligned}
& \text { o.a. -fo } \\
& \text { wo } \\
& \text { a-, ma-, e- }
\end{aligned}
$$

door prefixen, o.a. be-

$b e-$

$b e-$

door suffixen, o.a. $b a$ -

$b a-$

azon vóór naamw.

verscheidene prefixen

geen, (zelden : $-b o,-b \breve{e}$

$-i b)$

door suffixen

$-l u$ dezelfde suffixen ${ }^{1}$ )

$\left.w o^{2}\right)$
$\left.w o^{3}\right)$
$\left.a, m a^{4}\right)$
(pr. $3 \mathrm{p} . \mathrm{mv}$.
$\left.b e^{5}\right)$
$\left.b e^{6}\right)$
$\left.b e^{7}\right)$
$\left.b^{8}\right)$
$\left.b a^{9}\right)$
(a) won $\left.{ }^{10}\right)$

dezelfde prefixen ${ }^{11}$ )

$b \breve{e}^{12}$ )

door zelfde suffixen ${ }^{13}$ )

lu

Voor dit laatste zie Westermann: Charakter und Einteilung der Sudansprachen, Africa, vol. VIII, 1935, p. 140. Ter plaatse worden nog meer voorbeelden gegeven van pronomina die optreden als meervoudsaffixen. Voor het pronominaal karakter van deze affixen verwijst de schrijver naar zijn werk: Die westlichen Sudansprachen p. 303.

\footnotetext{
1) Geeft geen referentie op.

2) Christaller, Dict. Twi-Engl., 1933, p. XXIV.

3) Westermann, Gramm. der Ewe Spr., 1907, p. 47.

4) Westermann, Die Gola-Sprache, 1926, p.p. 39-50, 69-71.

5) Westermann, Die Sprache der Guang und 5 andere Togosprachen, 1922, pp. $43-47,50-51$.

6) Ibid., p. 77.

7) Ibid., p. 108.

8) Alexandre, Grammaire More, 1935, pp. $64-87$.

9) Lässig, Die Kussassi-Spr. in West Sudan, 1928, p. 42.

10) de Gaye and Beecraft, Yoruba Grammar, 1923, pp. 8-9, 28-29.

a11) Itmann, Die Sprache der Nyang, Zeitschr. für Eingeb., 1935-36, pp.
} 22-33, 111.

${ }^{12}$ ) Meyer, Mambila Studie, Zeitschr. für Eingeb., 1939-40, pp. 13-16, $30-33$.

${ }^{13}$ ) Cremer, La lengua Kassena, 1924, pp. 34-35.

D1. 102 . 
Wat de Indianentalen betreft werd minder materiaal onderzocht. Wij troffen hier ook hetzelfde verschijnsel aan. B.v. het meerv. van menschelijke wezens wordt in het Chinook gevormd door $t$ - dat oorspronkelijk de 3 e pers. mv. zou zijn: $\bar{\imath}^{\prime} k a l a$ : mensch; mv. tka $\left.\bar{a}^{\prime} l a u k s^{1}\right)$. In het Klamath wordt het meervoud van demonstratieven van levende wezens op dezelfde manier gevormd ${ }^{2}$ ). Er zijn nog meer voorbeelden ${ }^{3}$ ).

In andere taalgroepen zijn wij niet naar parallellen gaan zoeken. Het genoemde moge volstaan om aan te toonen, dat het geen zonderling en alleenstaand feit is, dat in het Austronesisch zekere talen het meervoud van substantieven op deze wijze vormen.

\section{$2^{0}$. Persoonlijke voornaamwoorden.}

In enkele talen vinden wij ook een vorm van het persoonlijk (of bezittelijk) voornaamwoord, waaraan een partikel is gehecht, dat gelijk is te stellen met de uitdrukking voor de derde pers. meerv., of gemakkelijk daartoe is te herleiden. Soms hebben wij daarnaast een 'korte vorm, zonder dat partikel.

Iloko: da-tayo, tayo: wij (incl.); in Tag. en Pang.: tayo. Da-kami, kami: wij (excl.). Da-kayo, kayo: gij (meervoud). Da-ta, $t a=\mathrm{Gij}$ en ik. De 3e persoon heeft speciale vormen. Lopez geeft hem als volgt :

Sing. Nom. $\left.{ }^{4}\right)$ : dédi, di, isú, isú dédi.

Gen. : dédi, na.

Cas. comm.: Kenkuana.

Plur. Nom. : dakuada, isuda, da, ida.

Gen. : $d a$.

Cas. comm. : Kadakuada.

Dédi is ook een aanwijzend voornaamw. Kenkuana kan worden ontleed in ken: casus comm. van het pers. lidwoord; kua: zaak, als zoodanig nog gebruikt; $n a$ is $3 \mathrm{e}$ pers. sing. gesuffigeerd, gelijk te stellen met Mal. nya. Dakuada ontleden wij in $d a+k u a+d a$; $d a$ is $3 e$ pers. plur. De samenstelling van dit woord komt niet zoo

1) Boas Fr., Handbook of American Indian Languages, Bur. of Am. Ethn., Bull. 40, Part I, p. 603.

$\left.{ }^{2}\right)$ The Klamath Indians, Contrib. to North-Amer. Ethn., Vol. II, Part. I, 1890 , p. 546.

3) Ibid., p. 463 .

4). Wij nemen hier over de gebruikelijke terminologie door de Spanjaarden ingevoerd. 
zonderling voor als men de volgende pronominale vormen vergelijkt: $i s u$ : $3 \mathrm{e}$ pers. sing., isu-da: $3 \mathrm{e}$ pers. plur.; tayo: wij, naast da-tayo met dezelfde beteekenis. In da-kua-da hebben wij dus twee keer het pronomen, vóór en na. De pronominale beteekenis van $d a$ zal hier wel niet meer aangevoeld worden; $d a$ is een meervoudig partikel geworden toegevoegd aan de pronomina zooals ook aan eigennamen en respektspersonen; dit zien wij verder.

Het Iloko heeft nog een kleine eigenaardigheid, die eveneens in het Gadang voorkomt. In het Iloko wordt, in bepaalde gevallen, de $3 \mathrm{e}$ pers. mv. gebruikt voor de eerste en tweede pers. mv. B.v.: gayem da kami : wij zijn uw vrienden; gayem da kayo: gij zijt onze vrienden. Zooals wij hierboven zeiden is in het Gadang de 3e pers. mv. : Nom. ira; Gen. $d a$. $D a$ wordt ook gevonden in de 2 e pers. sing. en plur. om de bezitsverhouding aan te duiden naast $n u, m u$ (sing.), diau, $y u$ (plur.).

Ifugaw. De volgende pronomina worden opgegeven:

Sing. 1e p.: haon of haoy; 2e p.: hea; 3e p.: hiya.

Plur. le p.: ditaku (incl.); 2e p.: dakayu.

dakami (excl.); 3e p.: dida.

dita (gij en ik).

$D i$ in ditaku, enz. zal wellicht gelijk zijn aan het lidw. di. $D a$ zou ik willen gelijkstellen met het pron. 3 p. mv., dat oorspronkelijk geen $d i$ voor zich had. Voor zoover mijn gegevens streken, komen kami en kayu niet voor ${ }^{1}$ ).

Lepanto. Hier vinden wij de volgende vormen naast elkaar: dakami, kami, da(i)tako, tako, daita, ta: wij. Dakayo, kayo: gij (meervoud).

Jamdeensch. Persoonlijke voornaamwoorden zijn: jakoe, kooe, ije, kite, kami, kmi, sire.

Bezittelijke voornaamwoorden: ningoe, nime, nije, ninde, mami, mire, nire.

Dus in de 2e pers. meerv. vinden wij een vorm op -re, die alleen in de 3 pers. meervoud verwacht wordt. Wij denken hier met een analogische formatie te maken te hebben.

Maar van het bezittelijk pronomen bestaat nog een versterkte vorm, die, juist als het substantief, het meervoudsteeken -ar krijgt. Zoo hebben, wij: ningwar, nimar, nijar, nindar, mamjar, mirar, nirar. In deze twee laatste zou tweemaal het meervoudsteeken zitten ${ }^{2}$ ).

1) Lambrecht Fr. P., Beknopte spraakkunst van het Ifugawsch. Nog in voorbereiding.

2) Voor verdere détails, o.c.p. 32 sqq. 
Hetzelfde vinden wij in het Fordaatsch en Slaroeëesch. Wij behoeven dat niet in het bizonder te bespreken.

Wij zagen boven, dat bij substantieven $d a$ dienst doet als pluralisator; daar beschikten wij over heel wat meer materiaal dan voor dit onderdeel van ons onderzoek; het lijkt me toch aannemelijk, dat wij hier met een overeenkomstig verschijnsel hebben te maken.

\section{$3^{0}$. Demonstratieven. Interrogatieven.}

Voor dit punt zijn weer van belang de Philippijnsche talen.

Pangasinan. Om het materiaal duidelijk te laten spreken geven wij de vormen van de 3 e pers. meervoud.

Nom. sicara, ra, ira.

Gen. $\left.d a^{1}\right), r a$.

Casus comm.: ed sicara.

De aanwijzende voornaamwoorden zijn:

Sing. Nom. saya, ia, áya: deze.

Gen. tonia, nasaya.

Dat. ed saya.

Acc. ed saya, na sáya.

Abl. ed saya, diad saya.

Plur. Nom. saraya, raya, iraya.

Gen. dania, na, saráya.

Dat. ed saráya, etc.

Sing. Nom. satan, tan, itan, atan, sosatan: die.

Plur. Nom, saratan, ratan, iratan, sosaratan.

Sing. Nom. Saman, man, iman áman: gindsche.

Plur. Nom. saraman, raman, iraman, sosaraman.

Sing. Nom. siopa, opa? Wie?

Plur. Nom. siopara, opara?

Het verschil tusschen enkv. en meerv. bestaat dus in (i) ra of $d a$.

$D a$ komt alleen voor in genitief, gepraefigeerd; $(i) r a$ in de andere naamvallen en wel als praefix (raya), infix (saraya), suffix (opara). Wij zullen de partikels $r a, d a$ verder nog ontmoeten bij het lidwoord.

Tiruray. Derde persoon meerv.: -ro, -re. Zelfstandig: berro (beis in alle pers. te vinden). Aanwijzende voornaamwoorden:

Sing. Nom. ini, eni, inide. De pluralis wordt gevormd door toe-

1) Pellicer M., Arte de la Lengua Pangasinan ó cabaloan, Manila 1904, p. 13 : $d$ en $r$ loopen in zekere gevallen door elkaar. Wisseling $d: r$ komt ook voor in het Latijn. Zie Sommer, Handbuch, p. 193. 
voeging van $-d e,-d o,-d a$. Het vragende voornaamw.: Sing. Nom. tino, $t i$, ati. Meerv. wordt op zelfde wijze gevormd.

Een woord ter verklaring. Terwijl de $3 \mathrm{e}$ persoon meervoud $-r o$, $-r e$ is, hebben wij $d$-vormen als pluralisator. Dit geeft niet veel moeilijkheid, als men bedenkt, dat men bij het persoonlijk lidwoord in het meerv. heeft $r e, r o$, in het andere lidwoord $d e, d o, d a$. Voor zooveel ik kon nagaan, treedt in het midden van het woord, in plaats van $d$, $r$ op. Wat de wisseling der vocalen betreft, deze is zeer gewoon op het einde van een woord in het Tiruray, niet alleen bij pronominale woorden, maar ook bij naamwoorden.

Gadang. Pronomen personale $3 \mathrm{e}$ pers. plurale $=$ ira. De demonstratieven worden in het meervoud gevormd door toevoeging van ira aan het enkelv. B.v. yau: deze, meerv. : irayau, yau ira.

Ibanag. Derde persoon meerv. ira (nom.), da (gen.), nira (casus comm.). Er zijn veel demonstratieven die alle verbogen worden als yau: deze, dit.

Sing. Nom. : yau, au.

Plur.: danau, annau.

Gen.: nau. Plur. : danau.

Casus comm.: tau. Plur.: taccaranau, taccuaranau.

Annau is misschien te verklaren uit adnau (metathesis en assimilatie). Taccuaranau bevat het meerv. van het persoonlijk lidwoord: taccua-ra. Het vragend voornaamwoord, dat gebruikt wordt voor personen, luidt in nom. sing: yasi, plur.: danasi. Voor zaken bezigt men anni. Dit heeft geen meerv.

Isinay. Aanwijzend voornw. : sari, die.

Verbuiging: Sing. Nom.: sari. Gen. : nari, disari. C. Comm. : siri. Plur. Nom.: sarari, darari. Gen.: darari, disarari. C. Comm. : sirari. 3e pers. mv. van het pron. pers. : dira.

$\begin{array}{ll}\text { Ifugao. Hantu : deze, } & \text { Plur.: Hantuda. } \\ \text { Hanna }: \text { die, } & \text { Plur.: Hannada. } \\ \text { Handi : gene, } & \text { Plur.: Handida. } \\ \text { Hituwe : deze, } & \text { Plur.: datuwe. } \\ \text { Hinae : die, } & \text { Plur.: danae. } \\ \text { hidaye : gene, } & \text { Plur.: dadie. }\end{array}$

Deze laatste drie pronomina worden gebruikt als men meer nadruk wil leggen. Men merke op, dat in de eerste serie $d a$ suffix is, in de tweede wordt $d a$ gepraefigeerd. De uitdrukking voor het pron. pers. is dida of $d a$. Het materiaal voor deze twee laatste talen kreeg ik toegezonden van P. Dr. Ampe, Leuven. 
Pampangan. Ini, iti: deze, plur.: deni, deti. Iyan: die, plur.: deyan. Ita: gene, plur.: deta. Nino: wie?, plur.: dinino, deno, careno?

Iloko. Hetzelfde partikel $d a$, dat wij in het persoonlijk voornaamwoord hebben ontmoet, en dat ook het meerv. is bij het persoonlijk lidwoord, meenen wij ook terug te vinden in de demonstratieven, maar, zooals we boven zeiden, zit er een moeilijkheid aan vast.

Sing. Nom. Gen. (i)toy, daytoy: deze, Plur. dagitoy, (i)toy.

Sing. Casus comm.: itoy, Plur.: kadagitoy.

De andere demonstratieven zijn: dayta, (i)ta: die; daydiay, (i)diay: gindsche. Hun meervoud wordt op dezelfde wijze gevormd, de verbuiging is gelijk boven.

Een eerste moeilijkheid: vanwaar de vormen daytoy, dayta, daydiay, naast (i)toy....? Hier kan men toch de pluralisator $d a$ niet veronderstellen. En vanwaar in het meerv. $g$ of $g i$, zoo men ontleedt in $d a-g$-itoy of da-gi-toy? Voor het laatste zou men kunnen denken aan $g i$, dat in Iban. gepraefigeerd, samen met het suffix -an, het meerv. van substantieven aangeeft. B.v. balay: huis, gibalayan: huizen. In het niet-persoonlijk lidwoord van het Iloko zit hetzelfde element als in de demonstratieven: (i)ti: Nom. Sing. In het meerv. : dagiti.

Soembaneesch. Wij zagen hierboven, dat het meerv. wordt aangegeven door $d a$ tegenover het enkv. na. Dezelfde oppositie treffen wij aan bij de demonstratieven waaraan deze partikels zich hebben vastgehecht. Enkv. nina, jeàna: deze, dit, meerv. nida, jeàda. Enkv. nana, noena: die, dat, meerv. nada, noeda ${ }^{1}$ ).

Mori. Derde persoon meervoud: ira, -do. Deze twee vormen behooren etymologisch samen ${ }^{2}$ ). In het Tinompo dialekt wordt het meervoud der demonstratieven gevormd door toevoeging van $-d o$. B.v. andio: deze; meervoud: andiodo $^{3}$ ).

Malagasy. Toen wij de pluralisator bij het pronomen personale behandelden, hebben wij het Malagasy onbesproken gelaten, omdat wij meenden in klaarheid te winnen, als wij het samennamen met de aanwijzende voornaamwoorden. De le persoon enk. en meerv. hebben een aparte formatie. Maar de tweede- en derde persoon hebben in het meerv. een pluralisator $r e$, die aan dat partikel doet denken, dat

1) Wielinga, o.c. p. 31 .

2) Esser S. J., Klank en vormleer van het Morisch. VBG., dl. 67, derde stuk, 1927 , p. 66.

3) Zie hierover $\S \S 172,176$. 
wij gelijkstelden met de uitdrukking voor de $3 \mathrm{e}$ persoon meervoud. We geven de vormen, die G. Ferrand ${ }^{1}$ ) rangschikt onder "Provinces", een dialekt. 2e pers. sing. : an $\overline{a o}$, plur. anare $\left.\overline{e O}^{2}\right)$; 3e pers. sing. : $\bar{\imath} z y$, plur. $\bar{\imath} z y,(\bar{\imath}) z \operatorname{ar} \overline{e o}, \bar{a} z y$. Het meerv. van al de demonstratieven wordt gevormd door re, b.v. $\overline{\imath o}$, deze, die, plur. ir $\overline{e o}$; ity: deze, plur. irēty. $R e$ is hier toegevoegd aan het lidwoord $i$.

Komen wij nu tot Melanesie. Verscheidene talen kennen ra als teeken van het meerv., vooral wanneer het personen betreft; jammer, dat de schrijvers het er niet altijd bijzeggen.

Wano (San Cristoval). Een algemeen demonstratief is na: deze. Meerv. naira.

Mota (Sugarloaf Island). Gai: die. Meerv. iragai. Volgens Codrington: $i=$ persoonsaanduider, $r a$ : meervoudspartikel.

Merlav (Star Island). Interr.: isei, wie? Plur. ira sei? Dit alleen voor personen gebruikt. Voor zaken sava, wat? Hij geeft geen meerv. aan van dit laatste.

Gog (Santa Maria). "The demonstrative made from the vocative vae! is irava, or rave; rave ta Qaur me ter gasagna gavrur? How do the Bauro people build their houses? irava is the Mota iragene, not iragai. There is also, corresponding to the Merlav words, ra melmer, vocative and demonstrative, you people! and those people; rarmer you two! and those two; ratolmer: you three! and those three; mer meaning boy, child“" 3 ).

Codrington zegt het wel niet, maar hij zal hier de vorming van het meervoud van het demonstratief voor oogen gehad hebben. Ik ben bang, dat hij hier, zooals elders, te veel geneigd is de aanwijzende woorden terug te brengen tot uitroepen.

Het interrogativum is (i)se, pl. irase. Dit wordt alleen voor personen gebruikt. Voor zaken heeft men $(u$.) sa, dat blijkbaar geen meervoud heeft.

Mosin (Vanua Lava).' Na gesproken te hebben over een demonstratief, dat schijnbaar alleen voor zaken gebruikt wordt, zegt Codrington: "Another (demonstrative) is $t i$, with the plural $r a$, ra ti: those persons; vet row mun rati: tell those people....".

Interrogatief: esei, plur. erasei. Voor zaken wordt een ander opgegeven zonder meervoud.

1) Ferrand G., Essai de Grammaire Malgache, p. 197.

2) Later komen wij hierop terug.

3) Codrington, o.c. p. 370 . 
Hierbij kunnen wij het laten. Meer materiaal is te vinden bij Codrington. Trouwens een deel van het materiaal, dat deze schrijver onder deze paragraaf brengt, zullen wij verder ontmoeten bij het lidwoord. Deze twee loopen door elkaar, vooral in de Melanesische spraakkunsten.

Onze conclusie is als boven. In verscheidene talen wordt het meerv. van de demonstratieven en interrogatieven gevormd door een pluralisator, die zich laat terugbrengen tot $d a$, dus de $3 \mathrm{e}$ pers. meerv. In een taal waar dit niet zoo duidelijk is mogen wij de identiteit met het pronomen vermoeden; ook nog wegens een feit, dat wij verder bespreken. Wij hebben ook kunnen constateeren, dat deze meervoudsaanduider vooral gevonden wordt met voornaamwoorden, die betrekking hebben op personen, minder vaak, wanneer zij staan voor zaken. Hetzelfde zal men kunnen opmerken bij het lidwoord en het honorifieke partikel dat wij er mede in verband brengen.

\section{$4^{0}$. Het Lidwoord.}

Boven zagen wij, dat $d a$ gebruikt wordt met de beide lidwoorden in het Iloko en het Tiruray.

Bisaya. Pron. 3e pers. sing. siya, plur. sira. Lidwoord voor eigennamen: sing. si Pedro, plur. sira Pedro: Petrus en de zijnen.

Pangasinan. Derde pers. sing. : sicato, plur. sicara; to en $r a$ stellen enkv. en meerv. tegenover elkaar.

Lidwoord voor eigennamen: sing. si Juan, plur. sara di Juan, sicara di Juan. Lidwoord voor gemeene naamwoorden: sing. Say too, so too: de mensch, pl. saray, iriya, ray, so saray too. De andere naamvallen kunnen wij onbesproken laten.

Lepanto. Juist als in het Iloko vinden wij hier $d a$ met eigennamen in het meervoud. Wij vinden $d a$ ook terug in het Ibanag $d a-n a-b i j$ verwantschapsnamen.

Chamoro. "Ha, welches unbetont vor dem Substantivum steht und berechtigterweise auch als Formans ha- aufgefasst werden könnte. Es wird benutzt in Verbindung mit Personennamen, und fasst Glieder einer Familie oder einer Anhängerschaft zusammen. Dieses ha ist identisch mit dem Element $h a$ in dem Fürwort der 3ten Pers. Plur. und geht zurück auf urindonesisches $d a^{\prime \prime}$.

Si ha Apo: die Familie Apo;

graha gipud as ha Luhan: bei Luhan ist ein Fest im Gange ${ }^{1}$ ).

1) Costenoble, o.c. p. 464 . 
Een bladzijde verder zegt hij nog: „In formeller Rede bedient man sich des aus dem pluralbildenden $d a$ entstandenen $h a$ in der Anrede, und zwar mit einer einzigen Ausnahme nur im Plural:

ha fangu'cu !: Freunde. Genossen!

ha fañes lo jan ha fansaday!: Brüder und Freunde!

ha fan' ${ }^{5}$ ăñago!: Mitmenschen!

Eine Ausnahme im Gebrauch und in der Form bildet: ăsayna Jus us!: „Herr Gott”!

Men merke hier op, dat de schrijver alleen voorbeelden geeft van eigennamen en namen van personen.

Soembasch. Het lidwoord in het Soembasch is in het enkelvoud na, in het meervoud $d a$. Dit laatste is ook $3 \mathrm{e}$ persoon meerv. B.v. Delinanja-ka na kataka na ama. Da anana, njoeda $i$ Omboe Ndiloe, dăngoe i Omboe Mada, dăngoe i Rămboe Kahi. Metika na inada. De vader sleep zijn bijl. Zijn kinderen waren.... Hun moeder was gestorven ${ }^{1}$ ).

Soloreesch. Hier eveneens gaat het pronomen van de derde persoon meervoud dienst doen als lidwoord. P. Arndt zegt hierover: „Zu den persönlichen Pronomina können andere Worte und Satzteile als nähere Bestimmungen treten; die Pronomina der dritten Person nehmen sich dann beinahe aus wie bestimmte Artikel. Die nähere Bestimmungen können sein: Substantive, Eigennamen, Ortsbestimmungen, Zahlwörter, Demonstrativpronomina, Indefinitivpronomina : ra' ata bereketen, (sie) die Tapferen; ra ina wae (Witi Hama dialekt) : die Frauen; ra' Sérang Gorang téti hau, die Leute von Sérang Gorang kamen vom Osten ${ }^{2}$ )".

Ngad'a. Misschien kunnen wij ook $d a$ in het Ngad'a hiermee gelijk stellen. P. Arndt beschrijft het gebruik hiervan aldus: „Die Partikel $d a$ wird bei Substantiven und substantivierten andern Wörtern in folgender Weise gebraucht:

1) bei Verwantschaftsnamen.... hat es den Sinn des Pron. poss. der 3. Person sein, ihr : da cĕma, der Vater, sein, ihr Vater. Auch sonst kommt da bisweilen in der Bedeutung sein, ihr vor; kiü da lima: seine Hand zerschmettern, rae da sä̈: sein Haus zerstören.

2) $d a$ mit folgendem Ortsnamen bedeutet soviel als ,die Leute von”; da Bena: die Leute aus Bena....

1) Onvlee L., Eenige Soembasche Vertellingen, Diss. Leiden, 1925, p. 52, 53.

$\left.{ }^{2}\right)$ Arndt P., Grammatik der Solor-Sprache, Ende, Flores, p. 43. 
3) dient es zur Substantivierung von Adjektiven, Verben und adverbiellen Ausdrücken; da ngai: der Reiche....

4) dient es zur Unterscheidung von Personen und Sachen, besonders bei Gegensätzen: vunga vunga zoze kole da susu, vaümuzi nö̈ zoze da lalu: zuerst schlachtet man das Weibchen, dann das Männchen.

5) auch vor hinweisenden Pronomina wird es gebraucht....: moli da Kĕnana: darauf” ${ }^{1}$ ).

Dit laatste doet ons voorzichtig zijn $d a$ hier gelijk te stellen met het pronomen. Trouwens wij vinden hiervoor een jongere uitdrukking:, micu: zij. Indien wij wat meer afwisten van de phonetica van deze taal, zouden wij misschien in staat zijn een conclusie te trekken.

Rottineesch. In deze taal hebben wij een pronomen van de $3 \mathrm{e}$ persoon: $a$, plur.: (a)la of (a)ra, dat ook als lidwoord kan worden gebruikt ${ }^{2}$ ). Elders ${ }^{3}$ ) zegt Jonker: " $l a(r a)$ is natuurlijk het $r a$, dat optreedt als pers. voornw. in de vervoeging, dat vervat is in sila, sira, en in het Soemb. in den vorm $d a$ ook de functie van een meervoudig lidwoord vervult.

In ala, ara, na een consonant zou de $a$ ingevoegd kunnen zijn $\left.{ }^{4}\right)$; evenwel valt nooit eenige nadruk op de eind-lettergreep van ala, ara, en, schoon het woord enclitisch gebezigd wordt, zou van het bijzondere accent op de laatste lettergreep waarschijnlijk toch nog wel iets overgebleven zijn ....". Dit laatste is mij alles behalve duidelijk.

Nog op een andere plaats spreekt hij over $l a, r a$. Wij zouden dit citaat vroeger vermeld hebben, was het niet zoo ondoorzichtig. Wij lieten liever veel materiaal voorafgaan om deze beschouwing duidelijker te maken. In acht genomen wat voorafgaat, lijkt Jonker's betoog niet zonder grond.

„Er is nog te spreken over het bij den meervoudigen vocatief voorkomende lemi -n, (lemi na, lemi -né, de $n$ blijkbaar eene verkorting van $n a$ of $n e ́$, zie $\S 122,216)$. Het bevat klaarblijkelijk het pers. voornw. emi, gijl.; in Korfabo zegt men ook eenvoudig kemi-é, in Bilba kemi-dé, (het laatste dé duidelijk in waarde gelijk aan é), ter-

1) Arndt P., Grammatik der Ngada-Sprache, VBG., D1. 72, derde stuk, 1933, p. 5 .

2) Zie Jonker, Rottin. Spr., § 164.

3) Ibid., p. 390, Aanm.

4) Gezien wij in het enkelvoud een eenvoudige $a$ hebben, moet men zoover niet zoeken; $a l a=a+$ de pluralisator of $3 \mathrm{e}$ persoonmv. $l a, r a$. 
wijl $\mathrm{Ba}$. lei-n(é) bezigt, gelijk het $e i$ heeft voor emi; Ti zegt nggara$r e i-n$; er ligt dus in lemi- $n$ een(e) $r(a)$ verscholen. In Dengka bezigt men nggelu-é, in Oen. nggeru-é of ama-nggeru-é. Nu is elu, eru, in beteekenis gelijk Term. la, Ti $r a$, als meervoudig lidwoord, dat als ala, ara, in de beteekenis van een pers. voornaamw. 3den pers. meerv. voorkomt ${ }^{1}$ ); blijkbaar is dus wel het eerste element nggara, in Ti $n g g a r a-r e i-n=n g g e l u, n g g e r u$. En denkelijk is de $l$ in lemi- $n$, le $i-n$, de $r$ in $r e i-n$, een overblijfsel van hetzelfde element, dat dus in het Ti-sche nggara-rei- $n$ tweemaal vervat is. In beteekenis kan het alleen versterking ${ }^{2}$ ) van $e m i$ zijn, gelijk dan ook een pers. voornw. van den 3 den pers. meerv. meermalen voor den 2 den pers. kan geplaatst worden; voor dit woord vgl. in 't bijzonder Bim. siara-e, gijl. van sia zijl. $^{3}$ ) Het ama-nggeru-é van Oen. bevat denkelijk ama = emi" ${ }^{4}$ ).

Om te beoordeelen wat Jonker zegt zou men in de talen van de streek wat moeten ingewerkt zijn. Voor zooveel ik hem begrijp, lijkt het mij niet onwaarschijnlijk, wat hij zegt, en in overeenstemming met wat wij zelf boven betoogden. Het is het meest diepgaande en het meest gezonde van al wat ik over deze kwestie kon vinden.

Gaan we nu over tot Melanesië om daarna nog een paar dingen op Indonesisch gebied te bespreken.

In het Maewo is het persoonlijk lidwoord $i$, meerv. ira. Hetzelfde hebben wij in het Oba, Arag, Mota, Merlav en Vuras. Ook wat het Motlav heeft komt op hetzelfde neer: sing. $i$, plur. $i r$. In het Mosin heben wij: sing. e, plur. era. Voor het persoonlijk lidwoord in het Wano geeft Codrington maar een vorm, nl. ia. Maar sprekende over het demonstratief zegt hij: "The third plural ira is also used as demonstrative: ira na Mara: the Malanta people". Men zou beter ira als een persoonl. lidw. bestempelen. Hetzelfde kan opgemerkt worden over wat hij zegt aangaande het demonstratief in het Mosin. Ra ta Mota vertaalt hij door the Mota people, en brengt het onder de paragraaf van het demonstratief. Sprekende over de demonstratieven in het Oba maakt Codrington nog deze opmerking, onkonsekwent en geen rede aangevend, "The plural $r a$ may be taken as a pronoun; ra ta Oba, the Oba people, $i$ ginew naha, or nehi or hii, this or that person, ira ginew nehi, those persons, ra garue, the two, ra gatolu,

1) M.i. moet het juist andersom geformuleerd worden.

$\left.{ }^{2}\right)$ Dit zegt weinig. Men zou ook aan andere mogelijkheden kunnen denken op grond van wat wij lieten voorafgaan.

3) Maar in Bim. Spr. geeft hij si- $a$ aan als $3 e$ pers. sing.

4) Rott. Spr., p. 331 . 
those three persons. But $r a$ has no more than personal and plural force, it belongs to the second person also, ra gatolu! ye three! vocative" ${ }^{\prime 1}$ ).

\section{Het honorifieke RA.}

In verscheidene talen hebben wij een honorifiek partikel $r a$, nl. in het Malagasy, Fidji, Formosaansch, Bare'e, Javaansch. Laten wij eerst zien wat daar elders over gezegd wordt en gaan wij dan de mogelijkheid na of wij dat $r a$ niet kunnen in betrekking brengen en identificeeren met de $3 \mathrm{e}$ pers. meerv.

Malagasy. Over dit partikel in deze taal zegt Ferrand: „Il se prefixe aux noms propres masculins et féminins. Cette ancienne particule nobiliaire est appliquée en malg. moderne à des noms de roturiers. Elle est devenue une simple particule de courtoisie. Exemples: Rabē, Monsieur Be, Ramangamāso, Madame Mangamaso. Préfixé à Andriana, il indique que le nom propre est masculin. Exemples: Randriamiādana, le prince Miādana, Ramiādana, la (princessè) Miādana" ${ }^{2}$ ). Wij vinden het ook in reny: moeder, etc.

Fidji. "Ra, frequently used before the name of a person, by way of respect, as $\mathrm{Mr}$. is with us. It is a contraction of Ratu. B. ${ }^{3}$ ). In Ragone, you children, (or Ralai, you little ones, Lau) it merely expresses the plu. nu. and is used only in the voc. case" ${ }^{4}$ ).

Formosaansch. „Het Singkansch Formosaansch heeft overeenkomende met het Javaansch $r a$, gewestelijk $z a$ (gespeld $s a$ ): rama, rena" ${ }^{5}$ ).

Bare'e. $R a^{-6}$ ) en $n d a^{-7}$ ) zijn beleefde voorvoegsels bij 3e pers. enkv. en mv. B.v. : $i$ Papa raintjani: Vader, ZEd. weet het; ndato'o $i$ Ine: HEd. heeft het gezegd, Moeder. Ra- en $n d a$ - zijn oorspr. de 3e pers. mv. ${ }^{8}$ ). Op een andere plaats ${ }^{9}$ ) spreekt Adriani van $r a$ - en noemt het een ,vereerend lidwoord ván eigennamen in poëzie, om iemand te onderscheiden dien men bezingt of toezingt". Hij voegt er

1) Codrington, o.c. p. 423,424 .

2) Ferrand, o.c. p. 184.

3) B. = Bau dialect.

4) Hazlewood, o.c. p. 94 .

5) Kern, V.G., VIII, p. 164.

6) Adriani N., Spr. der Bare'e Taal, Bandoeng, 1931, p. 342.

7) Ibid., p. 342: de nasaleering zou $r a$ - nog verfraaien.

8) Ibid., p. 341.

9) Adriani, De Beteekenis der vervoegde Vormen in het Bare'e, Ind. Gids, 1903 , p. 399. 
aan toe, dat $r a$ - niet meer als lidwoord wordt gevoeld, want een eigennaam met $r a$ - krijgt toch weder $i$ vóór zich. B.v. Koesale moënde anakoe i Ra-Gompi : ik noodig tot den reizang mijn dochter Jonkvrouw Gompi. Hij gaat verder en zegt, dat in sommige eigennamen $r a$ - een vast bestanddeel is geworden, b.v. Rantendo.

Dit $r a$ - stelt hij gelijk met $\left.l a-^{1}\right)$, dat ongeveer hetzelfde moet zijn. Hoe zij zich juist tot elkaar verhouden, zegt hij niet; aangezien $l$ wisselt met $r^{2}$ ), kunnen wij op de eerste plaats denken aan een dialectisch verschil, althans oorspronkelijk. Hij meent hetzelfde $l a$ - te vinden in het Mori en in het Boeg. B.v. Bare'e lamoa, (de titulaire benaming der gestorven voorouders) = Mori lahoemoa; het bestanddeel moa, zegt de schrijver, is identiek met het Baria mboa: geest. Maar er zijn bezwaren tegen deze opvatting. Vooreerst, zooals Adriani zelf voorstelt, zou la- in dit woord een verkorting kunnen zijn van lasa, dat hij nog in andere woorden abstraheert en noemt : ,een meervoudsof beleefdheidsvorm van la-". Lahoemoa zou komen van lasoemoa uit lasamoa. Een tweede bezwaar ligt hierin, dat $l a$ - in het Mori kan wisselen met $l i$-; in Morische eigennamen vindt men zoowel $l i$ - als $l a$. Deze vocaalwisseling wordt niet verklaard. En ten derde, indien $l a-$ in het Mori gelijk was aan het Bare'e la- en $r a$-, dan zouden wij deze vorm ook in het pron. pers. moeten terug vinden. Dit is niet het geval. Wel hebben wij ira, do, ro, maar geen la wordt opgegeven ${ }^{3}$ ). Men zou misschien kunnen vermoeden, dat $l a$ een oude vorm van het pron. is ${ }^{4}$ ), alleen bewaard gebleven in oude benamingen waar het een honorifiek partikel is geworden.

Wat la- in het Boeg. betreft, waar het gebruikt wordt voor mannelijke eigennamen, hier kan o.i. evenmin geverifieerd worden, of het samenhangt met het pron. pers.; $l$ kan een repraesentant zijn van oerIN. $d$, maar, zooals in zooveel andere talen, treden hier ook nog andere vertegenwoordigers $\mathrm{op}^{5}$ ). Zoolang de klankwetten in het Boeg. niet beter bestudeerd zijn, kunnen wij niet verder komen. Wij kunnen onze meening niet toetsen aan het pron.; voor de $3 \mathrm{e}$ pers. mv. hebben wij een jongere vorm: $n a$ - of (s)ia (= 3e pers. sing.).

Toba. Deze taal bezigt $d a$,bij substantieven, die een verwant

1) Ibid., p. 262.

2) Ibid., $\$ 47$.

3) Esser, o.c. p. 66: ira: zelfst. vorm; do, ro: geaffigeerde vormen met dialectisch verschil.

4) $r$ en $l$ kunnen wisselen. Zie ibid., nn. 88, 101.

$\left.{ }^{5}\right)$ Jonker, Rott. Spr. $\S 18$; Brandstetter, Sprachvergl. Charakterbild eines Ind. Idiomes, p. $54, \mathrm{~V}$. 
(sic!) aanduiden, dien men wegens ouderdom met eerbied moet bejegenen"' $\left.{ }^{1}\right)$. Eindigt het substantief op een klinker, dan sluit men het met ng. B.v. damang: (mijn) vader (ama), dainang: (mijn) moeder (ina), dahanang: (mijn) oudere broeder, zuster (haha).

Verder meent v. d. Tuuk, dat het gebruik van $d a$ vroeger meer uitgebreid was en vergelijkt het met OJ. en Mlg. $r a$, en Mal. da (b.v. in inangda). Het pron. van 3e pers. mv. = nasida (na-si-da).

Javaansch. 1) $R a$ wordt gevonden met namen van adellijke titels, respectspersonen en nog een paar andere. Bij een oppervlakkig onderzoek vond ik de volgende: rabrahmana, rāka, rakarayān, rakawi, rakryan, ranten, rāma, rahadyan, rahayu, rahina, reṇa, rāditya, rayi, rari, raputu, ranak, remboelan ${ }^{2}$ ), ratapa, rampu, rawiku, rakaki, rasaíhulun, rakĕmbar, ramatsyapati, e.a.

2) $R a$ zit ook in $d a-n g^{3}$ ) ,de oudere uitspraak van 't Jav., Malag., Fidji, enz. $\eta a$, dat deel uitmaakt van ratu, datu, Mal. datuq, ;Bat. datu, Fidji ratu, Tagal. dato, enz. In 't Oudjav. staat het als pers. lidw. vóór den titel of naam van hoogeerwaarde personen, als priesters, brahmanen, leeraars. Bijv. dang ācarya, de (geestelijke) leeraar ${ }^{4}$ )".

3) $R a$ in de anw. voornw. rasik $\breve{a}$, rasik $\breve{i}$, rasike, kenmerkt deze vormen als beleefd, zegt Kern. „Voorts is het duidelijk dat zij $i k \breve{a}$, die, en $i k \bar{\imath}, i k e$, deze, bevatten; hoe men de $s$ ook te verklaren hebbe, hetzij als de $s$ in Mandailingsch di siya, aan hem, haar, $t u$ siya, tot hem, haar, of als staande voor $\left.s i^{5}\right) \ldots$.

Weinig of niet verschillend van de zooeven genoemde woorden zijn sarikă en sariki. Sarikā Ādip. 42 slaat op den koning....”.

Wat den vorm van sarika en sariki aangaat, zou ik meenen dat rik $\breve{a}$ en $r i k \breve{l}$ bijwoordelijke locatieven zijn, beteekenende ,daar" en „hier”, vgl. Jav. ngrika en ngriki. Sa is de substantiefvorm van 't bijvoegelijke sang, en het hooge woord voor si. Sarika is dus zoo iets als „hoogstdezelve daar”; sariki, „hoogstdezelve hier”. Het is wel te begrijpen dat een vorst zich zelven aanduidt met ,hoogstdezelve daar”, als wilde hij te kennen geven dat hij te hoog en te ver staat om door

1) v. d. Tuuk, Tob. Spr., pp. $252-254$.

2) v. d. Tuuk, Kawi-Bal. Wdb., I, 688 ,

3) $-n g=$ lidwoord.

4) Kern, V. G., VIII, p. 164 ; Adriani, o.c., p. 239, noot, meent, dat in Bare'e datoe, titel van vorst v. Loewoe, een leenwoord uit Boeg., dit ra zit. Hij zegt niet hoe dat samenhangt met Boeg. la met zelfde bet.

${ }^{5}$ ) Het mand. pron. = iya, na prepos. = siya. Misschien is dit laatste de oorspr. vorm. Wat er ook van zij, voor het Jav. zou ik vermoeden: ra-si-ka; si als zoodanig bestaat nog en is persoonsaanwijzer 
de tegenwoordigheid van mindere wezens besmet te worden. In 't algemeen schijnt mij sarika een hooger rang of zaken van nog hooger waarde aan te duiden dan rasika" ${ }^{1}$ ).

Het lijkt mij heel onwaarschijnlijk, dat een vorst, op zich' zelf wijzend, zou zeggen ,die daar”.

Men zou een andere etymologie kunnen uitdenken, die evenmin als de voorgenoemde bewezen is, maar minder omslachtig. Sarika zou een metathesis voor rasika kunnen zijn, dialectisch gebruikt. Het feit, dat wij in het eerste gedeelte van het woord een $r$ hebben, die dikwijls aanleiding geeft tot dit taalverschijnsel ${ }^{2}$ ) - zou voor deze hypothese kunnen spreken.

Met dit materiaal voor oogen gaan wij trachten een verklaring te geven. Wij doen het niet zonder aarzelen.

Wij zagen, dat Kern de Formosaansche vorm gelijk stelt met de Javaansche, ook die van het Fidji en het Malagasy. De vorm in het Formosaansch heb ik phonetisch niet voldoende onderzocht ${ }^{3}$ ). Voor het Malagasy heb ik gezien, dat $r$ één van de vertegenwoordigers is van $d$. Wij zouden deze vier vormen willen terugbrengen tot $* d a$. Volgens de klankwetten van deze talen kunnen wij dat doen. Overigens, Bare'e $r a$ en Toba $d a$ stemmen hiermede ook overeen ${ }^{4}$ ).

Welke is nu de beteekenis van $* d a$ ?

Voor het Bare'e zagen wij hier boven, dat $r a$ - (of nda-) gelijk te stellen is met de 3 e pers. mv. In het Fidji gebruikt men in het eene dialekt $\mathrm{ra}$ - louter honorifiek, in het andere doet het dienst als meervoudsaanduider bij personen.... (zie hierboven). In het O.Jav. vinden

1) Kern, o.c., pp. 147, 148.

$\left.{ }^{2}\right)$ Voor : $r+$ voc. $+s$ zouden wij geen ander voorbeeld kunnen citeeren dan: lěrĕs, lěsěr: juist; rĕgěmĕn, grĕměn: als een groot lichaam z. voordoen, mag hier misschien ook geciteerd worden om meer grond aan onze hypothese te geven, al is het niet geheel en al hetzelfde geval. Deze twee gevallen van metathesis teekende ik terloops aan bij mijn lectuur. Indien men het Wdb. er op doorlas zou men vermoedelijk verscheidene voorbeelden kunnen noteeren.

3) Wel heb ik gezien, dat Form. $r$ inderdaad een vertegenwoordiger kan zijn van de RLD wet. B.v. roa twee, Jav. ro; borom, een sterke drank, Jav. bĕrěm.

4) Ferrand G., Essai de Phonétique comparée du Malais et des dialectes Malgaches, Paris, 1909, p. 126. Zie ook hierboven. Tagalen und Madagassen, 1902, p. 79, maakt Brandstetter een eigenaardige opmerking; ra, bloed kan niet beschouwd worden, zegt hij, als het zelfde als het hon. part., gezien dit laatste voornamer klinkt. Hij zal wel bedoelen: deze twee hebben niet dezelfde herkomst. Dit is inderdaad ook zoo. Mlg. ra, bloed = Jav. rāh, I1. dara; komt dus van *dara(h). Wijl andere het hon. $r a$ meenen terug te vinden in Tag. Bat. dato (datu), ziet hij de mogelijkheid in, dat het schuilt in Tag. lagoyo: vriend, en in Boeg. la-Muhamma. Tag. da- en la- worden dus praktisch geïdentificeerd zonder onderzoek naar de phonetische wetten. 
wij een parallel. B.v. Sampun padâmit mangkat maring ăçrama-nira bhagawān Wrgusuta: nadat zij afscheid genomen hadden vertrokken zij naar de kluizenarij van den eerwaarden $W$ rgusuta ${ }^{1}$ ). Tadanantara katwan ta sang Wṛhaspati, saking yoga bhagawān Nārada sira: dadelijk verscheen Wrihaspati, ten gevolge van de concentratie van den eerwaarden Nārada ${ }^{2}$ ).

Tadanantara hana ta sira brâhmaṇa těka: onmiddellijk daarop kwam er een brahmaan aan ${ }^{3}$ ).

Mangkana pakon bhagawān Byāsa ring çișyanira, tan langghana pwa sang (Wai) çampāyana, Samantu .... Parěng prea sira manguccāraṇa mantra pwa sira ....: Zoo luidde het bevel van den eerwaarden Byāsa aan zijn leerlingen. W., S .... gehoorzaamden. Zij reciteerden tezamen mantra's $\left.\ldots{ }^{4}\right)$.

Mangkana zenrerus bhagazūn Jāhnawīsuta ring sang Korawa sira kabeh..... aldus de woorden van den eerwaarden Jāhnawisuta tot al de Korawa's ${ }^{5}$ ).

In de twee laatste voorbeelden staat sira bij een meervoudig substantief. Het wijst niet het meervoud aan; het zou evengoed kunnen gemist worden zonder, dat de zin onduidelijk wordt. Het wordt alleen gebruikt omdat het hier gaat over voorname personen, het is louter honorifiek. In de drie eerste voorbeelden wordt het eveneens honorifiek gebruikt, maar bij een enkelvoudig begrip. Hadden wij hier te maken met niet in aanzien staande personen, dan zou dit woordje wegvallen. $\mathrm{Nu}$ zou men dit kunnen bedenken. Wij namen aan als oorspronkelijke vorm van de $3 \mathrm{e}$ pers. meerv. $d a$, zonder persoonswijzer $i$ of si. Verder weten wij, dat de voornaamwoorden voor de eerste en tweede pers. enkelv. en meerv. in het O. Jav. kunnen voorkomen met of zonder $s i^{\boldsymbol{b}}$ ). Wat de 3e pers. enkelv. betreft, veronderstelt Kern siya naast $y a^{6}$ ); de eerste van deze twee zou om zekere reden zijn verdwenen. Van de $3 e$ pers. meerv. spreekt hij niet, maar men moet een vorm $r a$ naast sira veronderstellen. Indien wij in de boven geciteerde voorbeelden $r a$ schrijven in plaats van sira, zouden wij best de mogelijkheid begrijpen, dat de $3 \mathrm{e}$ pers. meervoud zich tot een louter vereerend partikel kan ontwikkelen. Sira is de zelfstandige

\footnotetext{
1) Swellengrebel J. L., Korawãçrama, Diss. Leiden, 1936, pp. 38, 39.

2) Ibid., pp. 24, 25 .

3) Ādip., p. 205.

4) Koraw, p. 30, 31 .

5) Ibid., p. 34,35 .

6) Kern, V.G. VIII, p. 138.
} 
vorm, $r a$ wordt aan het substantief gepraefigeerd en groeit er, op de duur, aan vast $^{1}$ ).

In het Chamoro vinden wij ook steun voor deze opvatting. Wij citeerden: „Uber den Gebrauch des pluralen ha als Zeichen der Höflichkeit.... In formeller Rede bedient man sich des aus dem pluralbildenden $d a$ entstandenen $h a$ in der Anrede, und zwar mit einer einzigen Ausnahme nur im Plural". We gaven de voorbeelden. Hier hebben wij iets, dat heel dicht staat bij het gebruik, dat wij in het O. Jav. enz. veronderstellen. Het pronomen heeft zich ontwikkeld tot een honorifiek partikel, dat gewoonlijk staat bij namen van personen in het meervoud, maar ook een enkele maal met het enkelvoud. Voor het Toba $d a$ - nemen wij eenzelfde ontwikkeling aan. Het verschil tusschen het Chamoro en het O. Jav. - en het Toba - bestaat dus alleen hierin, dat in deze laatste taal het gebruik van sira heel gewoon is bij geëerde enkelvoudige personen, terwijl ha in het Chamoro bij uitzondering staat bij een enkelvoudig respectspersoon; aan deze term geef ik hier een ruime beteekenis.

Men kan ook nog het volgende in overweging nemen. Op de vorige bladzijden hebben wij naast het Chamoro verscheidene talen ontmoet, die als meervoud van het persoonlijk lidwoord hebben de $3 \mathrm{e}$ pers. plur., o.a. het Bisaya, Lepanto, Saloreesch, Maewo, enz. Deze talen kennen geen $3 \mathrm{e}$ pers. plur. bij het gewone lidwoord. Het onderscheid tusschen persoon en niet-persoon voeren zij ook elders door, b.v. bij de demonstratieven. $\mathrm{Nu}$, het persoonlijk lidwoord zou men, in het algemeen, kunnen betitelen als honorifiek partikel. Indien men zou aannemen, dat de meervoudige beteekenis van dit partikel is opgeheven door mechaniseering, zooals wij in het Fidji zagen gebeuren, waar $r a$ een louter vereerend partikel is geworden zoowel voor meervoud als voor enkelvoud, dan zouden wij niet alleen een verklaring hebben voor het feit, dat het pronomen zich zou ontwikkeld hebben tot een honorifiek lidwoord, maar wij zouden ook kunnen veronderstellen, dat wij in hooger genoemde talen een parallelle ontwikkeling hebben.

Dat men een pronomen, met oorspronkelijk meervoudige beteeke-

1) Als voorb. hiervan: ya ta tinadah dera Dwirada-Mada, ri jěngira sang rși, ndan sang apuputrâ, - nâdhukärâmisarja, sạha wacana amanis, lah sabhāgea, denira kakih patih. Een tweede voorbeeld om aan te duiden hoe ra is gaan verstarren in sommige gevallen. Yatika tinur wineh añakradhala, dera rakryan apatih. Hịer hebben wij twee keer $r a$; het eerste is tot één woord geworden met de, waarvan het een uitgebreide vorm is. Zie Berg, Kidung Pamañcangah, Santpoort, 1929, Zang I, vv. 19, 20.

D1. 102. 
nis, gaat gebruiken voor beleefd enkelvoud, hebben wij gezien in het O. Jav. en Cham. Ik heb het materiaal op dit punt niet onderzocht, maar wil nog een paar gevallen terloops aanstippen, n.l. in Tag., Toba, Sedik-Formosaansch en Mori. In deze laatste taal doet het bezitt. voornw. 3e pers. mv. - dat de gesuffigeerde vorm van het pron. pers. is - ook dienst als beleefd enkelv. B.v.: „rombia-do: hun, haar, (meerv. of beleefd enkelv.), zijn (beleefd) sagopalm"1). Dit gebeurde ook in de Indo-europeesche talen voor de drie personen. Bijv. het Duitsche sie voor de tweede en derde pers. enkelv.

De tweede persoon meervoud in het Nederl., Eng. en Fr., resp. gij, you, vous worden aanvankelijk gebezigd voor beleefd enkelv., later voor het enkelv. zonder meer. Iets dergelijks zal zich ook hebben voorgedaan op Austronesisch gebied. Dit zien wij b.v. ook voor $k i^{s}<k i t a$ in Boeg. en hita in Toba, dat als beleefd geldt in sing. en plur. Er zijn nog meer voorbeelden. Indien het zoo licht gebeurt, dat de meervoudige beteekenis van een pronomen verzwakt, dan zouden wij dat verschijnsel nog eerder kunnen onderstellen met een honorifiek partikel, dat, door het veelvuldig gebruik, op de duur in proklisis komt te staan met nomina, in een taalgroep, waar de uitdrukking van het meervoud door aparte affixen in het algemeen weinig is geprononceerd.

Ten bewijze hiervan kan men denken aan de zgn. passieve deelwoorden of het onpersoonlijk passief in verscheidene talen op Celebes. B.v. rabete tala: zij pletten bamboe; tala rabete: geplette bamboe ${ }^{2}$ ). Esser noemt dit $r a$ - de onbepaalde vorm van het werkwoord, en zegt, dat men in de 3e pers. m.v. ra een tweede maal gebruikt om onderscheid te maken met de genoemde vorm; b.v. ratoedoera: zij zullen bevelen ${ }^{3}$ ).

Indien men nu zou aannemen, dat het honorifieke $r a$ oorspronkelijk de 3 e pers. mv. was, dan zou er meteen klaarheid gebracht zijn in enkele duistere punten. Men zou kunnen vermoeden, dat de pluralisator $r e$, die in het Mlg. gevonden wordt in de tweede en derde persoon meerv. en in de plur. der demonstratieven, ook met Austron. $d a$ is te verbinden. Maar het vocalisme geeft een moeilijkheid. Iets dergelijks komt men meermalen tegen op Philippijnsch gebied.

Op de tweede plaats zouden wij een verklaring kunnen gissen voor

1) Esser S. J., o.c. n. 147.

2) Adriani-Kruyt, BST., pp. 126, 179, 181, 182, 183.

$\left.{ }^{3}\right)$ Esser, Koelawische Taalstudiën, Bandoeng, 1939, D1. II, p. 11. 
het partikel $(a) r$ in afhankelijke zinnen in het O. Jav.; (a) $r$ wordt gevonden met de $3 e$ pers. meerv. of $3 e$ pers. beleefd enkelv.; voor de andere personen worden andere partikels gebezigd die ook m.i. met hun pronominale vormen in verband kunnen worden gebracht. Kern noemt ze: ,verkorte vormen van persoonlijke voornaamwoorden" ${ }^{1}$ ). Voorloopig zal ik mij bepalen tot deze suppositie. Deze kwestie moet grondig onderzocht worden.

Ten derde zou men een vermoeden kunnen opperen omtrent het honorifieke ( $n) d a$ van het Oud-Maleisch. Coedès ${ }^{2}$ ) spreekt erover en zegt : ,nda pron. honorifique de la 3 . pers. encore employé en malais littéraire.... Dans cette phrase ...., Maka bagindapun mangkat-lah. Maka anakanda baginda Raja Iskandar Shah naik raja menggantikan kerajaan ayahanda," „Le roi mourut et le fils (de ce roi) monta sur le trôné de son père", l'enclitique -ṇda tient exactement la place qu'occuperait $-\tilde{n} a$ dans une phrase analogue mais se rapportant à des gens du commun.... De même que - ña est formé du pronom ya précédé de l'élément nasal qui a la valeur de l'article ou du relatif ${ }^{3}$ ).... n nda est évidemment formé de ce même élément suivi de $d a$ qui apparait dans dapunta (q.v.) et qui est plutôt un véritable pronom qu' un simple préfix, comme le dit M. van Ronkel”.

Wij willen deze hypothese nader omschrijven en verdere argumenten er voor in het geding brengen. Coedès spreekt maar van één vorm van het suffix, n.l. $n d a^{4}$ ); Crawfurd noemt het -anda ${ }^{5}$ ); bij van Wijk vinden wij $-d a$ en $-a n d a^{6}$ ). In werkelijkheid bestaat het suffix uit drie varianten, nl. : -anda, $-n d a$ en $-d a$. Hier volgt het materiaal, dat wij konden verzamelen:

ajah - ajahanda; anak — anakanda, anakda (a)nanda; adik $\left.{ }^{7}\right)$ adinda; bagi - baginda; bibi - bibinda; iboe - (in)boenda, bonda, kakak - (ka)kanda; mak — manda; mamak — mamanda; nénék - (né)nénda; oewa $(k)$ - oewanda; poetera - poeteranda; tjoetjoe - (tjoe)tjoenda; tjitji - (tji)tjinda; sahaja - sahajanda, sanda;

1) Kern, V.G., VIII, p. 278.

$\left.{ }^{2}\right)$ Coedès, Bulletin de l'Ecole franç. de l'Extr. Or., Tome 30, 1930, Nos. 1-2, p. 69 .

$\left.{ }^{3}\right)$ Niet erg gelukkig uitgedrukt; juister ware: de nasaal geeft de bezitsverhouding enz. aan. Zie Kern, V. G., VIII, p. 154.

4) Wij normaliseeren de spelling.

5) Crawfurd J., A Grammar and Dict. of the Mal. Lang, London, 1852, Vol. I, p. 70.

6) Van Wijk, Spr. der Mal. Taal ${ }^{2}, \S 87$.

7) De $k$ is hier en nog in een paar andere voorbeelden anorganisch. 
bidoean - bidoeanda; inang - inangda; mojang - mojangda $\left.{ }^{\mathbf{1}}\right)$. In O. Mal. inscripties vinden wij nog enkele voorbeelden: sabdakala sabdakalanda $\left.{ }^{2}\right)$; pranidhana - pranidhananda $\left.{ }^{3}\right)$; parva - parva$\left.n d a^{4}\right)$.

Deze vormen toonen aan, dat het suffix zich voordoet als -anda, -nda en -da. -Anda komt alleen voor in ajahanda en anakanda. M.i. is dit een jongere vorm van het suffix, ontstaan door metanalysis, naar kakanda, mamanda, etc. Hoewel Crawfurd in anakanda de oudste vorm ziet en in anakda een verkorte vorm, lijkt ons deze uitleg niet erg gelukkig; wij zouden dan moeten aannemen, dat -an- midden in het woord is weggevallen; van een dergelijke syncope zou ik in het Maleisch geen andere voorbeelden kunnen aanhalen. Blijft dan nog de dubbelvorm $-n d a,-d a$. Wellicht zal $n$, die in zooveel Indonesische talen de bezitsverhouding aangeeft, hier een rol spelen. Tot nog toe weten wij er weinig van. $\mathrm{Z}_{\mathrm{ij}}$ treedt in bepaalde gevallen op, in andere weer niet. Voor zooveel ik mij herinner komt ze vooral voor met $y$, $d, r$; ook wel met een andere klank ${ }^{5}$ ).

Beschouwen wij nu het materiaal van dichterbij. Wij hebben dus benevens het praefix $d a$ - (b.v. in dapunta, waarvan Coedès spreekt in boven aangehaalde plaats), een suffix in tweeërlei vorm: $-d a$ en $-n d a$. Algemeen wordt aangenomen, dat zij een honorifieke beteekenis hebben. Nu rijst de vraag: zijn zij van dezelfde natuur als $r a$ in het Javaansch en andere talen, zooals van der Tuuk meent ? ${ }^{\mathbf{6}}$ ) Of zou men niet kunnen veronderstellen, dat het oorspronkelijk vereerende titels waren, zooals padoeka, sri, in het hedendaagsche Maleisch? Wat $d a$ - betreft, lijkt ons, voorloopig althans, dit de eenvoudigste oplossing; waar wij in Jav. $r$ hebben, verwachten wij $d$ in Mal.; het zou ons onlogisch lijken voor $d a$ - een andere oplossing te gaan zoeken dan voor $r a$. En wat wij zouden moeten aannemen voor $d a$ zou ook gelden voor $-d a$, alleen met dit verschil: $d a$ - staat vóór het substantief als Jav. ra, dera of sira, -da komt er achter als Jav. ( $n)$ ira ${ }^{7}$ ),

1) Klinkert in Wdb. geeft nog senda $=$ pron. 2 pers., samengesteld uit $s i+$ $n d a$. Deze etymologie kunnen wij niet aanvaarden, want we zouden dan sinda moeten hebben.

2) Bijdr., D1. 100, 1941, p. $49 . \quad 3$ ) BEFEO, D1. 30, 1931, p. 39, 2 , 3.

4) In deze laatste voorb. hebben wij de spelling genormaliseerd zooals hierboven.

5) Voor $y$ liggen de voorbeelden voor het grijpen : $n y a$ naast $y a$ in veel talen. $Z$ ie ook Kern, V.G., pp. 150, 154. In dit geval kan moeilijk aan metanalysis gedacht worden; hiervoor zou alleen bidoean-da in aanmerking komen, dat zelden voorkomt.

6) Van der Tuuk, Tobasche Spr., p. 253, Aanm. I.

$\left.{ }^{7}\right) \mathrm{Wij}$ herinneren er aan, dat si- of ni- aanvankelijk niet vastgehecht waren an het pronomen; het zijn persoonswijzers die ook konden ontbreken. 
het gaf de bezitsverhouding aan. Zoo zou het mogelijk zijn, dat wij dit zelfde partikel nu eens vóór, dan eens achter het substantief vinden. Indien wij integendeel in $d a$ - of - $d a$ oorspronkelijk een zelfstandig naamwoord zouden willen zien, dat een titel aangeeft, hoe zouden wij dan deze wisselende positie moeten verklaren? Titels in het Maleisch hebben hun vaste plaats, zij gaan het woord vooraf waarbij zo hooren.

Nog minder zou deze veronderstelling opgaan voor -nda. Hoe is $n$ er bijgekomen of weggevallen, wanneer het niet de $n$ is, die zoo dikwijls gevonden wordt, in bepaalde klankcombinaties, om de bezitsverhouding aan te geven? Bovendien staat -nda steeds achter het substantief terwijl men het vóór het substantief zou verwachten, als het aanvankelijk op gelijke voet stond met padoeka, etc. Ook wordt -nda in O. Mal. gebruikt met zaaknamen, die betrekking hebben op vorstelijke personen, dus niet alleen met adellijke titels.

Wat de vorm van dit partikel aangaat, deze is niet in overeenstemming te brengen met de woordvorming van het Maleisch, ook niet met die van het Oud-Maleisch, voor zoover de gegevens strekken. Wij vinden geen enkel woord dat begint met $n d^{1}$ ). Dit zou er dus op wijzen dat $-n d a$ niet kan opgevat als een substantief van herkomst, maar wel als een suffix. Indien wij nu dit partikel opvatten als een pronominaal suffix, dan lijkt ons een woord als baginda, Zijne majesteit, duidelijk. Men ontleedt het in bahagia < Skt. deel, welvaart + $-n d a$. Wij zouden dan eenzelfde manier van uitdrukken hebben als in zooveel andere talen: de Welvaart van Z.Ed., Zijne Welvaart, Zijne Majesteit. Zoekt men naar een andere verklaring, hoe legt men dan deze zegswijze uit, en waarom vinden wij - $n d a$ niet gesuffigeerd aan andere titels? Zoo - $n d a$ aanvankelijk een pronomen was, dan kon het verwacht worden met bahagia, dat met dit suffix, zonder nadere toevoeging van de naam van den vorst, wordt gebruikt; padoeka en andere titels worden op zich zelf niet gebezigd.

Ook het volgende, dunkt mij, geeft grond aan deze hypothese.

Men kan met Coedès opmerken, dat de woorden, die eindigen op $-n d a$, anders dan de gewone woorden in het grammatisch verband behandeld worden: ze krijgen geen -nya. De reden hiervan zou mij niet duidelijk zijn, indien -nda oorspronkelijk een honorifiek suffix was zonder meer; waarom zou -nya bij deze woorden niet worden gesuffigeerd wanneer eenmaal $-\underline{n} d a$ een éénheid vormt met het woord?

1) Zie BEFEO, o.c., p. 69 . 
Wijst het gebruik, dat wij kennen, niet op een phase in het Maleisch, waarin -nda nog gevoeld werd als een pronominaal partikel, dat als dusdanig, op gelijke voet stond met -nya? Indien wij in $n d a$ een pronomen zien, wordt het meteen duidelijk waarom wij alleen bij deze categorie van woorden geen -nya aantreffen; het zou terug gaan op een oudere toestand waarin $n d a$ gelijkwaardig was met $-n y a^{1}$ ).

Tot nog toe kunnen wij niet verder argumenteeren uit het Maleisch zelf. Wij hebben in andere talen naar parallellen gezocht en gevonden.

Hierboven maakten wij de opmerking, dat verscheidene talen de 3e pers. meerv. gebruiken voor beleefd enkelv. Wij noemden toen o.a. het Tag., Toba en Sedik-Form. De twee eerste hebben alleen de langere vorm van het pron., resp.: nila en nasida; deze worden niet gesuffigeerd. Het Sedik-Form. heeft als suffix het oudere -na bewaard; het gebruikt sida in deze functie niet. Wel zagen wij, dat het Mori de kortere vorm -do van het pron. 3e pers. plur. suffigeert als beleefd enkelv. Wij trokken ook de aandacht op het feit, dat het Gadang dit pronomen gebruikt in de 2e pers. sing. en plur. De grammatika zegt wel niet, dat het een beleefde vorm is, maar hij is, zooals zooveel andere, op dit punt erg onvolledig; wij kunnen vermoeden, dat dit gebruik, althans in oorsprong, respectvol is bedoeld. In het Iloko wordt dit pronomen gebruikt in bepaalde combinaties voor de 2e pers. m.v. Voor zooveel ik weet, heeft het hier deze nuance niet. Ander en beter materiaal vinden wij op Celebes. In het Bare'e luidt de korte vorm van de 3 e pers. mv. $r a$, nda, $a$, volgens de dialekten. Deze wordt als beleefd enkelvoud gebruikt. B.v.: $i$ Papa raintjani: vader, Z.Ed. weet het; ndato'o $i$ Ine: H. Ed. heeft het gezegd, Moeder $^{2}$ ); ananda H. Ed.'s kind ${ }^{3}$ ); taboa: Z. Ed's, H. Ed's (en mv.) drinknap ${ }^{4}$ ).

Dit zouden ontwikkelingen kunnen zijn die parallel loopen met Mal. $-n d a$; ze geven een redelijke verklaring maar geen afdoende bewijs. Indien wij meer dergelijke gevallen konden aanstippen zou onze,

1) Iets wat hiermee in verband kan gebracht vinden wij bij de To Pebato's. Zij gebruiken, zooals hun buren, niet het honorifieke $-a$, maar ook niet $-n y a$. Zie Adriani, o.c., p. 342 .

2) Adriani, o.c., pp. 337,342 .

3) Ibid., p. 343.

4) Ibid., p. 10 .

Wij meenden ook het materiaal, dat Dr. Haaksma p. 47 van zijn Diss. „Inleiding tot de vervoegde vormen in de Indonesische Talen", 1933, aangeeft voor het Engganeesch te kunnen gebruiken. Hij citeert het uit Bijdr., D1. 72, 1916; het is echter te vinden in D1. 71, 1915. Hij geeft als pron. 3 p. enk. : kia, -dia, $-n i a,-n a-d a$. De plaatsen, die hij voor deze laatste vorm citeert, slaan op het 
argumentatie versterkt worden en overtuigend zijn. Wij gelooven, dat indien men verder zou gaan zoeken, men meer parallellen zou aantreffen. Men mag echter niet vergeten, dat de voorbeelden, die wij aanhaalden om te verklaren, hoe de $3 \mathrm{e}$ pers. mv. tot een louter vereerend praefix kan worden, hier ook kunnen worden vergeleken.

Voor wij hiervan afstappen, willen wij een laatste punt aanroeren dat de grammatici heeft beziggehouden. Indien $-n d a$ (of een variant hiervan) van huis uit de 3 e pers. mv. zou zijn, welke verklaring moet men dan zoeken voor het feit, dat in enkele zeldzame gevallen er toch nog een pronomen gesuffigeerd wordt? Gerth van Wijk, over deze kwestie handelend, zegt: „Deze woorden nemen geen bezittelijk pronominaal suffix achter zich, daar dit reeds in den vorm opgesloten is; ajahanda beteekent mijn, uzv, zijn vader, al naar het verband van den zin dit medebrengt; alleen boenda makt hierop een uitzondering, misschien wel omdat dit woord, door het verliezen van de eerste lettergreep, een vorm heeft aangenomen die het niet onmiddellijk tot een afgeleid woord stempelt; zoo b.v. : . . ja boenda-koe: o (mijn) moeder, maka kata boenda-nja: toen sprak zijn moeder'. In een noot ${ }^{1}$ ) geeft hij ook nog voorbeelden van ajahanda-nja ${ }^{2}$ ). Om reden, dat - $d a$ en -nda een pronominaal suffix kunnen krijgen, meent Tendeloo, dat deze partikels niet eens suffixen zijn:, gering is het aantal woorden, waarin men dit element aantreft, en de Maleier beschouwt deze als grondwoorden, zooals onder andere blijkt, dat hij spreekt van boendanja, wat hij zeker niet doen zou indien hij nog de kracht gevoelde van dit eertijds levende formatieve element" ${ }^{3}$ ).

De redeneering van Tendeloo houdt o.i. geen steek, en wel om deze twee redenen. Niets is er tegen, dat wij een opeenstapeling van „levende" suffixen zouden hebben. De voorbeelden zijn zonder tal zoowel in de Indonesische ${ }^{4}$ ) als Indo-europeesche talen ${ }^{5}$ ). Veel minder

meerv. Hier een voorb. door mij zelf gekozen, dat aantoont, dat - $d$ a meervoud is. Bijdr., D1. 71, p. 533. De Mal. vert. geven wij ook.

E. Kidikoeda kakia hade ilopo eana kahai ekaka.

M. Ditjeritrakan adalah doeloe dinegrie itoe satoe orang.

E. Kaha iphiada hi honania, moö kanio $B$.

M. pergi keladangnja dengan bininja jang bernama $B$.

Wij zochten ook tevergeefs in Spr. en teksten naar de vormen -dra, -ndra, die Dr. Haaksma, p. 39 van hetzelfde werk, voor het Měntawai opgeeft.

1) Van Wijk, o.c., p. 219.

2) Zie ook Hikajat Pandji Semirang4, Volkslect., nr. 48, p. 16 et passim.

3) Tendeloo, Mal. Gramm., II, p. 100.

4) Denk aan de met suffix samengestelde zelfstandige naamw. en werkw., gevolgd door het gesuffigeerde pronomen.

5) Bijvoorbeeld alleen nog maar de flectievormen. 
nog kan men de mogelijkheid daarvan bestrijden wanneer het geldt een ,eertijds levend formatief element" met een nog levend suffix, wat hier het geval zou zijn. Denken wij b.v. aan het Nederl. schoen, oorspronkelijk het meerv. van schoe; omdat de vorm schoen als pluralis niet meer zoo duidelijk was, voegde men er nogmaals het meervoudssuffix -en aan toe. Kinder was eerst het meerv. van kind. Omdat dit meerv. afweek van de meest gewone vorm op -en, kreeg het nogmaals het teeken van de pluralis en werd kinderen. Zoo zijn er veel voorbeelden. Voor het Indonesisch zagen wij, dat o.a. in het Soembaneesch de $3 e$ pers. sing. en plur. twee keer achter elkaar worden gebruikt. De voorbeelden, die wij aanhaalden, toonen de mogelijkheid aan van opeenhooping van een en hetzelfde suffix.

De veronderstelling van $\mathrm{G}$. van $\mathrm{Wijk}$ lijkt ons eveneens onaannemelijk, wanneer hij meent, dat het toevoegen van het pron. -koe aan boenda misschien zijn verklaring vindt in het feit, dat dit woord zijn eerste lettergreep verloren heeft. Hij vergeet, dat inboenda ook voorkomt; ook al kwam deze vorm niet voor, en al hadden wij alleen boenda naast iboe, dan zou men dit nog een gewaagde hypothese moeten achten; naar analogie van zooveel andere vormen die paarsgewijze voorkomen zullen o.i. boenda en iboe in het taalbewustzijn als correlatief angevoeld worden. Bovendien wordt deze veronderstelling weerlegd door een ander voorbeeld, dat van Wijk zelf geeft. Ajahanda-nja verklaart hij niet op deze wijze en het kan ook aldus niet uitgelegd worden; niettemin wordt -nja gesuffigeerd. De schrijver drukt zich onduidelijk uit wanneer hij zegt, dat de woorden, uitgaande op dit suffix, geen pronomen gebezigd wordt omdat het er in ligt opgesloten. Hoe is het er in begrepen? Hoe komt het, dat ajahanda zonder toevoeging van het pronomen even goed voor de eerste persoon kan gebruikt worden als voor de tweede en derde, voor enkelvoud en meervoud? Wij zouden evenmin deze vraag kunnen beantwoorden, tenzij wij zouden mogen aannemen, dat dit gebruik teruggaat tot een periode in de taal, waarin -anda (en beide varianten) gevoeld werd als een levend element, als het pron. $3 e$ pers. plur.; zoolang deze functie levend bleef, kon geen nieuw pronominaal suffix toegevoegd worden en werden deze vormen zonder andere affixen gebruikt. Pas later, toen de beteekenis van het pronomen vervaagd was en alleen het honorifieke element overbleef, kon men er mee aanvangen een nieuw pronomen te affigeeren en kreeg men stapelvormen. Dit zou de huidige toestand zijn in het Maleisch. 


\section{Het plurale ar, $\breve{e r}, a l$, $\breve{e l}$ in het Soendaasch.}

In het Soendaasch wordt soms het meervoud van substantieven en werkw. gevormd door één van de affixen $a r, \breve{e r}, a l$, $\breve{e l}$, dat voor het woord staat, zoo dit met een klinker begint en als infix optreedt, zoo het met een consonant aanvangt ${ }^{1}$ ). Bijv. boedak: kind, meerv. b-ar-oedak; oelin: spelen, meerv. ar-oelin.

De vraag rijst nu: kunnen wij ook dit ar- met het pronomen verbinden, zooals Jonker meent ${ }^{2}$ ). Wanneer men sommige feiten uit de Phil. talen in overweging neemt, zou men voor die hypothese kunnen voelen. B.v. Pang. sáya: deze, meerv. saraya; satan: die, meerv. saratan. Nu gelooven wij voor de Phil. talen genoegzaam te hebben aangetoond, dat $r a$ hier oorspronkelijk het pron. pers. was. Met het Soendaasch is er toch een verschil: wij hebben niet $r a$ maar $a r$ in deze taal.

Meer zouden wij nog voor deze onderstelling kunnen voelen als wij in het Bikol (Phil.) het volgende zien. „Het partikel mag- dient om verwantschapsbetrekkingen en dgl. te vormen; b.v.: magamá: vader en zoon (of dochter); magtugang: twee broers ${ }^{3}$ ).... Wanneer er meer dan twee zijn wordt er een der volgende syllaben geinfigeerd: $r a, r i, r o$ (naarmate de eerste vocaal $a$, $e$, of $o$ is) .... na de eerste vocaal. Wij zijn allen broeders: mag-tu-ru-gang ,(tugang) $\left.{ }^{4}\right)$. Verder nog: „Het meervoud van deze substantieven (nl. 'de compañia' als Ned. mede-student) wordt gevormd door $r a, r i$, ro te infigeeren. B.v. magcaiba: twee metgezellen; magcairiba drie of meer metgezellen" ${ }^{5}$ ).

Dus het meervoud bestaande uit een drievoudig, viervoudig.... subject heeft als kenmerk $r a$ of een ander infix; deze zullen oorspronkelijk wel één en hetzelfde zijn geweest. Indien de feiten in het Bikol waren zooals in zooveel van zijn zustertalen, zouden wij daarin ook een uitlooper van het pronomen kunnen gissen. Maar, voor zooveel ik zie, treedt hier het pronomen als pluralisator niet op; ik kan geen enkel geval verifieeren. Wij moeten dus op onze hoede zijn voor lichtvaardige hypothesen.

Een andere omstandigheid, die wij in verband met het Soendasche ar.... kunnen brengen, is de volgende. In het Mentawei kan het pron.

1) Zie: Oosting H. J., Soendaasche Grammatica, Amsterdam 1884, § 113 sqq. en Coolsma S., Soendaneesche Spraakkunst, Leiden, Sijthoff, p. 163.

2) Jonker, Over de vervoegde, werkwoordsv. Bijdr. K. I., 8e volgr. I, p. 277.

3) Schrijver zal wel bedoelen: twee gebroeders $z i j n$.

4) De Vera R.M., R.P., Gramática Hispano-Bicol, Manila, 1904, p. 31.

5) Ibid., p. 32. 
pers. tusschen voorvoegsel en stam van het werkw. staan; b.v.: $a-n u-k u \dot{n a n}$ : gij hebt gezegd, a-ra-kua: zij zeggen. Het voornw. kan ook tusschen twee praefixen ingeschoven worden: $a-r a-p a-s ̌ a b u$ : zij zijn verdwenen.

In het Olon-Maanjan (Borneo) hebben wij een geinfigeerd ar met plurale beteekenis. „Die mit $b a$ - gebildeten Wörter bedeuten: sich mit etwas beschäftigen, etwas betreiben: ba-gawai - arbeiten, $b a$ dagang - Handel treiben.... das im Substantiv genannte besitzen, haben oder gebrauchen.... Das Präfix bara- kann nur dann Anwendung finden wenn das Subjekt im Plural steht. Es wird nur selten gebraucht" 1 ).

In het Bare'e komen de volgende affixen voor: $l a-, l e-, l i, l o, l o e^{-}, r a-$, $r i, \mathrm{ro}^{-}, \mathrm{roe}^{-2}$ ). Deze kunnen praefix of infix zijn. Na veel voorbeelden te hebben opgesomd van vormen met deze affixen naast andere zonder affix, concludeert hij: ,uit deze voorbeelden is te zien, dat de beteekenis der besproken voorvoegsels in vele gevallen geheel is teloorgegaan. Waar de beteekenis van het prefix zich nog laat gelden, daar is het die van ,gelijkend op, zijnde als het grw." Maar waar behalve het prefix $l a-, r a-$, enz. nog een voorvoegsel als $m a-, k a-, b a-, p a-, t a-$ enz. aanwezig is, zoodat de samengestelde prefixen mala-, mara-, molo .... enz. ontstaan, daar wordt een frequentatief infix $a l$-, $a r o l$, or in het voorvoegsel gevoeld, zoodat de beteekenis zich daarnaar richt en ook frequentatief wordt, in 't eene geval meer, in het ander geval minder ${ }^{3}$ ). Bladz. 346 vinden wij dit: ,Een meervoudsvorm van se' $i$ is sare' $i$ (infix -ar-), die niet wordt gebruikt ter bepaling van ieder meervoudig woord, want $s e^{\prime} i$ is evengoed enk. als mv. Sare'i geeft aan het woord, dat het bepaalt, een algemeene beteekenis, weer- te geven met ,deze en zijns (haars) gelijken, deze heele soort”, bv. bara ngiromo komi, ngkai? 'Tampe ngkoempoe, taoe toe'amo sare' $i$ : is $\mathrm{U}$ al tandeloos, grootvader? Natuurlijk, kleinkind, menschen die al zoo oud zijn als ik."

Williams maakt ook enkele opmerkingen over $\left.a l, a r^{4}\right), \ldots$ Im Sang. (Adriani S. $151 \mathrm{ff}$.), Battak und Jav. hat dieses Infix eine frequentative oder intensive Bedeutung. Im Bisaya bildet $l i$ oder $l o$ Diminutiva; Intensiva werden durch umala gebildet (Mentrida S. 194

1) Bijdr. D1. 67, 1913, pp. 210, 211.

2) Adriani, o.c., § 164 .

3) Zie ook $\S \S 143,146$ sqq., $\S 185$.

4) Williams H. W., Grammatische Skizze der Ilocano-Sprache, InauguralDissertation, München, 1904, p. 40. 
und 178). Im Bikol bildet ar Diminutiva. Im Iloko gibt es einige Fälle, wo dieses Infix scheint vorhanden zu sein. Vgl.....: alipunged, Verdriesslichkeit mit punged, hartnäckig und pungtot, Zorn; pinak, die Hälfte mit palinaak, die Hälfte...."

Wat betreft de vormen met $l, r$, enz. naast vormen zonder die klanken bracht Prof. Gonda veel licht in zijn bijdrage : „Some remarks on onomatopoeia, sound-symbolism and wordformation à propos of the theories of C. N. Maxwell", Tijdschr. Ind. T. L. V., Dl. LXXX, 1940, Afl. 2. Met veel materiaal toont hij aan, dat wij niet altijd behoeven te denken aan een oud infix maar ook wel aan „Streckformen" met een onomatopoeisch karakter of iets dergelijks ${ }^{1}$ ).

Ik heb het materiaal niet van dichtbij onderzocht, maar heb de indruk, dat wij hier met meer dan een phenomeen hebben te maken; voor het Mentawei is het duidelijk, dat wij de verschijnselen niet op dezelfde voet kunnen stellen als het Soendaasch, enz. Voor wij hier tot een oplossing kunnen komen zal al het feitenmateriaal moeten verzameld en grondig bestudeerd worden. Ik raakte de kwestie hier aan om de aandacht te vestigen op een gezichtspunt dat, voor zooveel ik weet, in dit probleem altijd over het hoofd is gezien. Men kan de vraag stellen: kan het pron. pers., verstard tot pluralisator, zooals in veel andere talen, niet worden tot een praefix met plurale beteekenis en nadien door metathesis infix worden met behoud van die beteekenis?

$\mathrm{Nu}$ gaan wij over tot het corrigeeren van enkele opvattingen die met onze conclusies niet stroken.

Sprekend over Il. da zegt Williams : „Vermutlich is $d a$ (Iloko) ein Mehrzahlzeichen $=$ viele. Der Gebrauch als Personalpronomen hätte sich also aus diesem entwickelt. Man könnte auch das $d a$ vom Altjav. datu (und Fiji ratu, Herr, Häuptling), welches ein persönlicher Artikel zu sein scheint, vergleichen" ${ }^{2}$ ). Hij citeert Adriani, Sangir. Spr. p. 239: „Indien de laatste lettergreep $r a$ het uit versch. talen bekende meervoudsteeken is, dan is sira het mv. van si en beteekent dus, de velen".

Wij zeiden in het begin van dit opstel, dat wij ons de ontwikkeling juist omgekeerd voorstellen: primair is o.i. het pronomen, dat later

1) Zie pp. 161 sqq., 183, 193 sqq. Een opmerking die hiermee kan verband houden vond ik nog bij P. Geurtjens, Spr. der Keieesche Taal V. B. G., D1. 63, 1922, p. 9. Zie ook BST. III, p. 98. Hiermee zal het materiaal wel niet uitgeput zijn.

2) Williams, o.c., p. 48. 
is gaan dienst doen als pluralisator. Wij meenen te hebben aangetoond, dat het honorifieke $r a$ samenhangt met het pronomen; Williams denkt er ook zoo over maar bewijst niets. Zonder dit te citeeren zegt Brandstetter: „The plural pronoun $r a$ and the honorific particle $r a$ ( $\S \S 91$ sqq.) are identical. We have a parallel in the Karo pronoun kena. This is the pronoun of the second person plural you, without any nuance of politeness, but it can also be used in addressing a single person, and then it is polite" ${ }^{1}$ ).

Brandstetter ziet dus in $r a$ hetzelfde woord als in het pronomen. Maar in $\mathrm{n} .130$ van dezelfde verhandeling, waar hij het pron. 3 pers. plur. bespreekt, geeft hij geen vorm $r a$ op, wel (s)ira, (na)sida. Hij verwijst ook naar $\S \S 91$ sqq., maar daar handelt hij alleen over het honorifieke $r a$ in het O. Jav., Hova en Fidji. In n. 96 zegt hij : ,, $r a \ldots$ only one function appears to be common IN. viz. its use an article". Hij bedoelt het honorifieke partikel.

Deze twee schrijvers brengen dus het pronomen, het pluralis- en honorifieke affix samen. Hoe ze samenhooren, zeggen zij niet en hun opvatting bewijzen zij evenmin. $\mathrm{Zij}$ hebben zich aan een gissing gewaagd, die wij ook hebben gemaakt, onafhankelijk van hen. Wij hebben echter naar bewijsgronden gezocht en die gediscuteerd.

Wat $r a$ betreft in O. Jav. ratu (vorst), Tag. datu, enz., waarin Kern, Williams en Brandstetter (n. 92) het honorifieke $r a$ zien, kunnen wij dit zeggen, zoo ons voorafgaand betoog wordt aangenomen. Indien wij hier werkelijk te maken hadden met het honorifiek partikel, zouden wij in het Tagalog *lato (koning) verwachten naar het pron. sila, en wij hebben dato. Maar we mogen de mogelijkheid niet uit het oog verliezen, dat wij hier een ,kruising” in de klankwetten kunnen hebben; misschien met assimilatie van lato tot dato? Dit zou moeten worden onderzocht; het zou wellicht een argument meer in het geding brengen voor of tegen onze opvatting. Men kan dit nog opmerken: indien O. Jav. ratu, enz. zoo was te ontleden, waarom zouden wij dan in het Tagalog en Batak dit praefix alleen in dit woord kunnen aanwijzen, en toevallig in hetzelfde? Andere woorden worden niet opgegeven $^{2}$ ).

Brandstetter, sprekende over de 3 pers. sing. en plur., zegt : „Wenn aber $i a$ aus $i$ und $a$ besteht, dürfen wir auch den kamberischen Artikel $n a$ in $n$ und $a$ zerlegen, denn der Artikel $n$ existiert ja auch für sich im Bare'e. Und wenn wir den Singular $n a$ in $n+a$ zergliedern,

1) Brandstetter, Common Indonesian and original Indonesian, n. 131.

2) Zie ook noot 3, p. 63. 
so müssen wir konsequenter Weise die entsprechende Operation auch beim Plural $d a$ vornehmen und ihn in $d+a$ anatomisieren, wenn schon ein Artikel $d$ nirgends existiert" ${ }^{1}$ ).

Wat Brandstetter hier zegt en doet, klinkt en is al te chirurgisch. Met de anatomie toegepast op de sing. wil ik mij niet zoozeer inlaten. Alleen lijkt het mij, dat wij hier in de eigenlijke zin geen lidwoord, maar wel een pronomen - misschien wel een verstard - hebben. Hij citeert voor het Kamberisch: na lima: „Die Hand; na lima na: seine Hand; da lima na: Seine Hände. Zoo we nog aanvaarden wat hij beweert voor het enkelvoud, niets wettigt ons a pari te besluiten tot eenzelfde ontleding van $d a$; trouwens de schrijver in kwestie voelt zelf aan, dat hij daartoe geen positieve bewijsgronden kan aanvoeren. Naar onze meening is $d a$ in het Kamberisch oorspronkelijk geen lidw., maar pron. Een voorbeeld van Brandstetter zelf makt het duidelijk: „da katiku da da lua: die Köpfe von ihnen, den Luas, die Köpfe der Lua-Pflanzen" ${ }^{1}$ ). Zooals de schrijver zelf zegt, is Kamb. $d a$ identisch met meervoudig lidw. la van het Rottineesch, volgens de RLD wet ${ }^{2}$ ).

Asai geeft de volgende vormen voor het pron. 3 pers. van het Sedik-Form.

Sing.

lange vorm korte vorm

Nom. hida

Plur.

Gen. nida

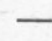

Obl. hida

na

Pag. 47 zegt hij: ,hida is primarily an adverb of place meaning the far invisible place ${ }^{\prime}$ and sometimes used to indicate a person who is at the far invisible place. Dahida also means things or persons at the far invisible place".

Vooreerst merken wij op, dat, zooals vroeger is gezegd, (si) oorspronkelijke vorm was van het pron. 3 pers. plur. Wij hebben verschillende talen aangestipt waar dit meervoudig pronomen gebruikt werd in het enkelv. Voor zooveel wij nu voor het Sedik kunnen nagaan, beantwoordt hida aan Austr. sida. Op een andere plaats zegt de schrijver : ,The lingual $r$ (die wij altijd als $\underline{d}$ aangaven) becomes $\underline{d}$. The phenomena of this $r$ are explained with the RLD Law by Dr.

1) Brandstetter, Der Artikel, n. 39 I.

2) o.c., n. 63.

3) Asai ,Some observations on the Sedik Language of Formosa, Philologia Orientalis, 'I', 1934. 
R. Brandstetter. Common IN parai, hulled rice, $>$ padai $\left.{ }^{1}{ }^{1}\right)$. De gelijkstelling van de andere klanken in hida kan ik bij Asai niet verifieeren; zijn behandeling van de klankleer is verre van volledig.

Bovendien blijkt onze opvatting de juiste te zijn, als wij sing. en plur. vergelijken: hida en dahida. Da stelt beide getallen tegenover elkaar en is dus pluralisator. Wij kunnen vermoeden, dat het een korte vorm is van het pronomen. Wij zouden hier iets kunnen hebben als in het Iloko: da-cua-da: zij; da-tayo wij; da-cayo: gij (plur.). Hierop wil ik niet verder ingaan.

Als korte vorm van het pron. 3 pers. sing. wordt na aangegeven. Men kan vermoeden, dat $n a$ de gesuffigeerde vorm is, gebruikt b.v. in de bezitsverhouding; dit is in ieder geval een zeer verspreide vorm. Maar dit $n a$ beantwoordt nergens aan sida, wel aan $y a$ of iets dergelijks. $Y a$ zou hier de plaats hebben geruimd voor siḍa, en alleen behouden zijn gebleven als suffix. Van dit gezichtspunt ook blijkt onze voorstelling van zaken juister te zijn.

$\mathrm{Nu}$ is dit de eenige plaats van alle beschouwingen, die wij doorgenomen hebben, waarin gezegd wordt dat sida oorspronkelijk beteekende: „the far invisible place”. Indien dit werkelijk zoo was, dan zou men voor de plur. verwachten: ,the far invisible places”. Maarneen, Asai zegt: ,dahida means things or persons at the far invisible place". Hier steekt dus een inkonsekwentie in en daarom ook vinden wij de vertaling van hida: ,the far invisible place" verdacht. Asai kent wel beter deze taal dan wij, maar, als wij ons niet vergissen, berust zijn studie alleen op een paar oude aanteekeningen. Men zou de waarde van deze dokumenten moeten nagaan.

Hier knoopen wij bij aan een opvatting van P. Geurtjens; hoewel niet juist, is ze leerrijk. Hij zegt in zijn spraakleer der Keieesche taal: „Een eigen meervoudsvorm hebben de woorden niet. Oorspronkelijk heeft er waarschijnlijk wel een meervoudsvorm bestaan op ar of $r$, zooals we die nog in 't Jamdeensch geregeld en in 't Fordaatsch sporadisch aantreffen. Men vindt daarvan nog sporen, bv. in 't pers. voornw. $i$, hij, meerv. hir, zij, of $e r$ als persoonlijk praefix van den derden pers. meerv. bij de werkwoorden; het bezittel. voornw. $n i$, zijn ; rir of hirrir, hun ...." ${ }^{1}$ ). Hir en er vatten wij op als een dubbelvorm, teruggaande op sida; rir en hirrir lijken ons stapelvormingen.

Maar hier, dunkt mij, hebben wij de proef op de som van de

1) Asai, o.c., p. 13.

2) Geurtjens, V. B. G., D1. 63, 1922, p. 9. 
meening die wij vooruit zetten tegen Codrington, Adriani en Williams, die, ten onrechte beweren, dat de oorspronkelijke beteekenis van $d a$ is het meervoud.

In de 3 e pers. meerv. alleen zou de pluralisator $(a) r$ bewaard zijn gebleven, en overal elders verdwenen. Neen, voor zooveel wij weten, is hij in het Kei nergens verdwenen, en wij treffen $(a) r$ alleen daar aan waar hij verwacht kan worden.

In het begin van deze verhandeling gaven wij een kort overzicht van de stof die wij zouden behandelen. Wij achtten het noodig dit te laten voorafgaan als leiddraad in een opstel dat niet veel meer bevat dan feitenmateriaal met een korte verklaring. $\mathrm{Nu}$ zou ons nog de taak resten, dat nader te interpreteeren en een oplossing trachten te geven van de vragen die in de loop van deze studie zijn gerezen. Op het oogenblik kunnen wij daarop niet ingaan.

Wij zeggen onze oprechte dank aan onze Professoren Gonda en Gerlach Royen, die zoo goed zijn geweest dit opstel na te lezen en het op menigvuldige plaats hebben gecorrigeerd; zij deden ons ook materiaal aan de hand, dat wij, niet zonder veel nut, hebben aangewend. 